
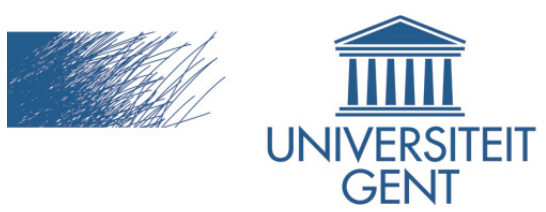

biblio.ugent.be

The UGent Institutional Repository is the electronic archiving and dissemination platform for all UGent research publications. Ghent University has implemented a mandate stipulating that all academic publications of UGent researchers should be deposited and archived in this repository. Except for items where current copyright restrictions apply, these papers are available in Open Access.

This item is the archived peer-reviewed author-version of:

Slope aspect affects geomorphic dynamics of coal mining spoil heaps in Belgium

Nyssen, J., Vermeersch, D.

In: Geomorphology, 123 (1-2), 109-121, 2010.

doi:10.1016/j.geomorph.2010.07.004

To refer to or to cite this work, please use the citation to the published version:

Nyssen, J., Vermeersch, D. (2010). Slope aspect affects geomorphic dynamics of coal mining spoil heaps in Belgium. Geomorphology 123 (1-2), 109-121. doi:10.1016/i.geomorph.2010.07.004 
Nyssen, J., Vermeersch, D., 2010. Slope aspect affects geomorphic dynamics of coal mining spoil heaps in

Belgium. Geomorphology, 123: 109-121.

POST PRINT

\title{
Slope aspect affects geomorphic dynamics of coal mining spoil heaps in Belgium
}

\author{
Jan Nyssen ${ }^{*}$, Dominiek Vermeersch \\ Department of Geography, Ghent University, Krijgslaan 281 (S8), B-9000 Gent, Belgium
}

Corresponding author. Tel: 0032926446 23; Fax: 003292644985.

E-mail address jan.nyssen@ugent.be (J. Nyssen)

\begin{abstract}
After the abandonment of coal mining in Belgium in the 1960s-1980s, many coal tips have been left to themselves. Increasingly, these coal tips are regarded as socio-cultural heritage and protected for their environmental value. This research analyses the spatial distribution of the main geomorphic processes (sheet and rill erosion, landsliding, rock fragment movement and root throw) occurring on coal tips in Belgium, through mapping of the processes and their causal factors. Five spoil heaps spread over the major coal basins were studied in detail. The spoil heaps were subdivided in homogeneous land units, especially with regard to slope gradient, vegetation cover and slope aspect. Qualitative and quantitative observations were done on processes and potential causal factors. Regressions showed that generally, the expression of slope processes on the studied coal tips is (1) strongly dependent on westerly aspect of the slopes, (2) independent of slope gradient (which presents a narrow range), (3) impeded by grass cover, and (4) not fully predictable due to variability in type and age of dumped mine spoil.
\end{abstract}

Key words: Sheet and rill erosion; Slope aspect; Landslide; Gully erosion; Rock fragment; Technosol

\section{Introduction}

The 19th and 20th century's mining industry in Belgium left about 360 coal tips (EspaceTerrils, 2008), which determine large parts of the landscape in the provinces of Limburg, Liège and Hainaut. In the Wallonia region, more than half of the population lives within visual distance of a coal tip (EspaceTerrils, 2008). Since the abandonment of coal mining in Belgium in the 1960s-1980s, most coal tips were left standing without any major human interference; some were levelled and others have been utilised for recreational purposes. Currently, and increasingly, these coal tips are regarded as a part of Belgium's socio-cultural heritage (Corne and De Keghel, 2006a,b; EspaceTerrils, 2008; Mijnerfgoed, 2008; Blègny-Mine, 2010; Maison des Terrils, 2010).

Coal tips ("terrils" in the Belgian language forms of Dutch and French) are composed of various materials, primarily sterile rock but also waste such as mine wood, scrap metal, and scoria from surface facilities. Rocks composing Belgian coal tips belong to the Westphalian and Namurian (approx. $320 \mathrm{Ma}$ ) and include psammites, shales and coal residues (Renier, 1944). 
Worldwide, the geomorphology of mine spoils (sensu lato) and their reclamation has been studied. Surface hydrology has been investigated (Haigh and Sansom, 1999; Evans et al., 2000; Nicolau, 2002; Rovis-Hermann et al., 2002), also in relation with the problem of transported pollutants (Loredo et al., 1999). Research on slope processes reported in literature includes sheet and rill erosion (Evans et al., 2000; Willgoose and Sharmeen, 2006; Hancock et al., 2008) and the subsequent armouring (Willgoose and Sharmeen, 2006), gully erosion (Evans and Willgoose, 2000) and particularly landsliding (Taylor and Spears, 1972; Monjoie et al., 1985; Monjoie and Schroeder, 2001; Carpentier et al., 2005). Surprisingly, the movement of rock fragments over the surface of mine spoils and the causes and effects of the widely present root throw seem not to have been studied. At the scale of coal-tip systems, catchment (Willgoose and Riley, 1998) and relief evolution (Willgoose, 1994; Paithankar et al., 2001; Hancock et al., 2003; Nicolau, 2003) as well as total soil loss (Haigh and Sansom, 1999; Boggs et al., 2000; RovisHermann et al., 2002) have been addressed. No sediment budget studies were encountered in literature, and it seems that the depositional areas have been far less studied than the source areas.

A certain number of studies have focused on the causal factors of the magnitude of geomorphic processes on mine spoils, such as type of slope material (Haigh and Sansom, 1999), vegetation type and cover (Masson, 1950; Jochimsen, 1996; Haigh and Sansom, 1999; Evans and Willgoose, 2000), the role of self-ignition, combustion and subsequent transformation of shales (Harrington and East, 1949; Carpentier et al., 2005), time (Taylor and Spears, 1972; Evans and Willgoose, 2000; Rovis-Hermann et al., 2002) and slope gradient (Hancock et al., 2008). The impacts of slope aspect, and related microclimate, on slope processes on spoil heaps have been touched upon (Cornwell, 1971; Jochimsen, 1996; De Munck et al., 2009). The geographical distribution of erosion activity seems not to have been studied in the light of regional variations in climatic parameters (rainfall depth as well as spatial and temporal distribution, or frost activity for instance) or of material composing the mine spoils.

Finally, a large body of studies addresses the issue of coal-tip reclamation through the application of various engineering techniques (Hüttl et al., 1996; Fox et al., 1998; Evans and Willgoose, 2000; Paithankar et al., 2001; Hancock et al., 2003), whereby studies analysing the role of spontaneously grown vegetation receive less attention (Jochimsen, 1996; Hodačová and Prach, 2003).

With regard to the 360 Belgian "terrils", research papers including geomorphic features are few and far in between (Calembert and Dantinne, 1965; Monjoie et al., 1985; Palmers, 1995; Corexenos, 2001; Monjoie and Schroeder, 2001; Detalle, 2006). In this research we have identified and analysed the spatial distribution of the main geomorphic processes occurring on five coal tips in Belgium (Fig. 1), through mapping of the processes and their explanatory factors. The study links up the degree of expression of sheet and rill erosion, gully erosion, landsliding, root throw and deposition, with vegetation densities, rock fragment characteristics, slope gradient and aspect as well as combustion of coal residues.

*** Figure 1 approximately here $* * *$

\section{Study area: the Belgian coal tips}

\subsection{Coal mining in Belgium}


The formation of coal layers in terrains that are now the north-west European continent took place during Westphalian times (300 Ma ago, part of the Late Carboniferous period). At the apogee of the Hercynian orogenesis, a mountain chain separated the Mediterranean area from the North German bight, a shallow marshy area ideal for the development of coal. Most coal basins in Europe are located at the position of what was then the North German basin (Goossens, 1984; Minten et al., 1992; Brink, 2005). Both in the northwestern Kempen region, and in the southern Belgian axis (Borinage-Centre-CharleroiLiège) coal layers of the same ages occur; they are however thicker and deeply buried in the Kempen (Goossens, 1984; Minten et al., 1992).

Though coal had been exploited on a small scale in Belgium since the 12th century, a major coal extraction industry developed only in the 19th century in the Walloon industrial axis, concurrently with those in the adjacent northern France and German coal bearing regions (Rasmont and Barbier, 2000). In Limburg the exploitation started only in the early 20th century due to difficulties in locating and extracting the deep-seated coal (Lohest et al., 1904; Mijnerfgoed, 2008). Until the 1960s, coal was the most important source of energy in Belgium. Since then, coal mines were gradually closed, and the last coal mines ceased operation in Wallonia in 1984, and in the Kempen in 1992 (Monjoie and Schroeder, 2001; Mijnerfgoed, 2008).

\subsection{Coal tips}

With coal exploitation, spoil heaps were erected, and their shape and volume evolved in parallel with the mining technologies. The oldest coal tips, 'fourfeyeux' in the local Walloon language, appeared in the 12th century and were $<10 \mathrm{~m}$ high due to limited extraction technology, and because essentially only coal, and little waste was brought to the surface. In the second half of the 18th and in the 19th century, extraction techniques improved and led to much larger flattened 10-20 m high 'plats-terrils' with a volume of around $100000 \mathrm{~m}^{3}$. By the end of the 19th and during the 20th century, the 'terrils' reached heights comprised between 60 and $90 \mathrm{~m}$ and their volume increased to more than $600000 \mathrm{~m}^{3}$. The top of these spoil heaps was often conic, but other forms were made, depending on the way in which debris was dumped (Debehault, 1968) and the underlying shape of the original land surface that was covered by dumping. Waggons were trolleyed to the top over a linear slope of around $30^{\circ}$; the angle of respose of the debris was 35$40^{\circ}$. Tracks were moved as the coal tip increased in height, and sometimes iron sheets were placed so that toboggans could bring debris to the desired place. Hence, the topography of coal tips is typically one of adjacent, diverging downslope oriented ridges and valleys (Debehault, 1968).

The coal tips are composed of waste material from the underground mines, and are mainly (often finely crinkled) shale and sandstone. To separate coal from stony waste, dense medium baths were used (Sanders, 2007). This technique employed the difference in densities between coal (1.3-1.4 $\left.\mathrm{kg} \mathrm{L}^{-1}\right)$ and shale $\left(2.2-2.4 \mathrm{~kg} \mathrm{~L}^{-1}\right)$. In a medium with intermediate density (water with magnetite), stones sank and coal floated. In time, the separation techniques were improved and the content of coal in mine spoil heaps decreased, from an average $15 \%$ in the older tips to $5 \%$ in the more recent (Debehault, 1968).

In the Kempen region, the coal tips have been established on thick Quaternary aeolian sands, while in the more southern basins, they generally lie on around $10 \mathrm{~m}$ of Quaternary 
loess over Palaeozoic bedrock. In the latter areas, there is sometimes an intermediary gravel-rich river terrace that occurs between the loess and bedrock (Pissart and Macar, 1976). In the regions where the coal tips have been established in Belgium, most rain originates from maritime south-westerly/ westerly weather systems, and there is an average rainfall of 700-1000 $\mathrm{mm} \mathrm{yr}^{-1}$, with 170-180 rainy days per year;

\subsection{Establishment of vegetation on coal tips}

After exploitation, the spoil heaps have been colonised by vegetation, growing from seeds that were brought in by avian and aeolian dispersion. Species with light seeds (birch, grasses, and spore plants) have been found to dominate, followed by those with heavier seeds (oak, hazel, beech, sycamore, and ash). Fruit trees and shrubs such as buckthorn are disseminated by birds (Debehault, 1968). In a first stage, vegetation cover is poor and geomorphic processes are active. When the spoil heap is completely covered by forest, the slopes are more or less stabilised; yet, the variability in tree species has an impact on the magnitude of the geomorphic processes.

The presence of Mediterranean vegetation, with species as Clematis vitalba (calciphile), Carlina vulgaris and Senecio inaequidens, especially on poorly forested southern slopes, is explained by the arid environment, linked to high permeability, absorption of sunlight by dark shales and to a certain extent by wind speed (Debehault, 1968; Monjoie and Schroeder, 2001). The northern slopes are less exposed to drought and often better forested (Debehault, 1968; Frankard, 2000).

Zones that show evidence of combustion are not occupied by vegetation if the temperature exceeds $50^{\circ} \mathrm{C}$, but if the surface temperature ranges between $20^{\circ} \mathrm{C}$ and $45^{\circ} \mathrm{C}$, the characteristic vegetation (Digitaria sanguinalis, Vulpia myuros and Spergularia rubra) is related to a very particular microclimate, where the ground never freezes, and vegetation stays green throughout the winter though it will dry rapidly in summer (Debehault, 1968; Frankard, 2000).

In humid temperate climate, forests colonise coal tips which are essentially not polluted. Such vegetation develops in another way than a planted forest, where the colonisation by vegetation takes place more rapidly and is deemed more efficient (Haigh and GentchevaKostadinova, 2002; Hodačová and Prach, 2003). In case of natural reforestation, shallowrooted birches will be dominant for a long period and are expected to poorly stabilise the slopes (Frankard, 2000). In reforestation there is a strong preference for Robinia pseudoacacia, which is deep rooting, stabilises slopes, grows rapidly even on stony soils and enriches the soil in Nitrogen, what in its turn enhances succession. Furthermore, it tolerates acidity (Debehault, 1968; Bradshaw, 1997). Other reforestation species on coal tips include oak, sycamore, ash and wild cherry (Debehault, 1968).

\subsection{Future of coal tips}

One of the options for coal tips is the recovery of the coal fraction, at least in those heaps that have sufficient coal content and which do not burn. The whole coal tip is then excavated and the residu sometimes placed back at the same location. The materials have been used for railway (own observations) and highway embankments (Debehault, 1968; Monjoie and Schroeder, 2001). The red shales in coal tips that have burned are used for footpaths and tennis courts. Now that coal tips have become 'green', operations of their removal meet great resistance, as nature value would be lost, and years of dusty 
conditions would be created by processing and transport (Charlier, 2000; Frankard, 2000; Raes and Bosteels, 2006).

Semi-natural uses of coal tips are impeded by their steep topography, active settlement processes and the acid environment. Informal herding of sheep, goats and sometimes cattle takes place on several of them, and some south-oriented slopes have been used for the establishment of vineyards. Most commonly, reforestation takes place (Debehault, 1968; Bradshaw, 1997, 2000; Hodačová and Prach, 2003), which leads to problems in areas where pollutants have been incorporated in the materials of the spoil heap (Loredo et al., 1999). Currently, the nature and recreation values of spoil heaps are being developed by local authorities (Ledent, 1993; Charlier, 2000; Corne and De Keghel, 2006a,b; Raes and Bosteels, 2006; EspaceTerrils, 2008; Mijnerfgoed, 2008; BlègnyMine, 2010; Maison des Terrils, 2010).

\subsection{Coal tips selected for the study}

After field explorations on 14 coal tips in Belgium, five spoil heaps, spread over the major basins of the country were selected (Table 1, Fig. 1). To have comparable conditions, only coal tips that have not been reworked or reshaped were chosen, mostly conical ones. Fully vegetated heaps were also avoided in order to be able to study variability in slope processes.

*** Table 1 approximately here $* * *$

The $75 \mathrm{~m}$ high terril de l'Héribus is the westernmost spoil heap that was studied. The coal tip is covered with trees on its northern slopes as well as on the gentler slopes (about $10^{\circ}$ ) which make the link from the foot to the higher parts of the tip, where slopes become steeper $\left(30^{\circ}\right)$. This is the only one of our five coal tips which has a formal recreation function: stairs and footpaths were installed, as well as some benches and an orientation table. Near the top, combustion occurs (Monjoie and Schroeder, 2001), which led to a local nickname "Mount Erebus". In recent years, two debris slides have occurred. The western slide took place suddenly in summer 1992, after an intense storm; a slower eastern slide occurred in 1994 and blocked a road (Chemin de Bavay) (Monjoie and Schroeder, 2001).

The base of the terril du Boubier in the Charleroi basin is located at $150 \mathrm{~m}$ a.s.l. on the edge of a terrace of the River Sambre. The spoil heap is only forested on the northern slope, on the other slopes there is steppic vegetation with only some sporadic trees (Fig. 2).

*** Figure 2 approximately here ***

The terril de la Petite Bacnure is located near Liège; it has a conical shape, with an elongated top, part of which is burning. On 1 April 1999, after a heavy rain, a $1344 \mathrm{~m}^{3}$ debris slide (Nyssen et al., 2010) occurred on the burning side of the heap (Fig. 3).

*** Figure 3 approximately here $* * *$

The top of the Hasard coal tip, $10 \mathrm{~km}$ east of Liège, at $360 \mathrm{~m}$ a.s.l. is the highest of Belgium and offers a $360^{\circ}$ wide panorama over the main geomorphic regions of Middle and High Belgium. In 2002, a debris slide occurred in a burnt area, yet it was not clear whether the combustion was still active at the time of the slide (Detalle, 2006). 
On the Kempen plateau, one of the three spoil heaps of Waterschei was selected. Here, a particular feature is that the materials were deposited within only 8 years, from 1953 to 1961 (Palmers, 1995). One must further take into account that driving of cross motor cycles takes place on this spoil heap, which may particularly enhance rill and gully erosion.

\subsection{Processes that affect geomorphic activity on the studied coal tips \\ 2.6.1. Runoff and infiltration}

Runoff from spoil heaps, with their steep slope gradients and low vegetation cover, is deemed to be relatively limited due to high permeability which is related to the coarse material that they are composed of. On the other hand, lignite spoil heaps in Germany show high water repellency (Gerke et al., 2001; Buczko and Gerke, 2005; Hangen et al., 2005), which is also assumed to exist on the Belgian coal tips, and which leads to locally high densities of rills. Locally gullies may occur in depressions where the water concentrates, but they are few, as also observed by Debehault (1968) and Corexenos (2001).

Infiltrating water on the other hand enhances the oxidation of pyrite (Zodrow, 2005) and replenishes aquifers. High infiltration may lead to temporary saturation and ultimately to land sliding.

\subsubsection{Soil compaction}

Soil compaction related to settlement occurs within the mass of the coal tip and enhances runoff or may hinder root penetration. Less evidence of runoff was clearly observed in places with dense vegetation, not the least because the vegetation leads to better infiltration (Haigh and Sansom, 1999).

\subsubsection{Acidification}

Coal tips have often a toxic environment due to soil acidification which is related to oxidation of pyrite (Urrutia et al., 1992; Zodrow, 2005). This acidification is a slow process which may take a few decennia and lead to a $\mathrm{pH}$ of 3. As a solution, Bradshaw (2000) suggests natural leaching or liming to neutralise the soil.

\subsubsection{Spring development}

Springs exist at the foot of the Boubier (Fig. 4) and many other spoil heaps. Corexenos (2001) describes the three springs at the foot of Bernalmont near Herstal. The occurrence of these springs is related to the much higher hydraulic conductivity (Shepherd, 1989) of the spoil heap with its large and unlayered clasts, as compared to the underlying natural formations, in many cases Quaternary loess, which have furthermore been compacted by the weight of the spoil heap itself.

$* * *$ Figure 4 approximately here $* * *$

\subsubsection{Spontaneous self-combustion}

Evidence of combustion was observed on four of the five studied coal tips, and has been reported on many other coal tips (Nyssen et al., 2010). Coal mine tips have variable contents of coal (5-15\%) as well as iron sulphides (pyrite and marcassite). The coal content found in the tips depends on the age of the spoil heap; older spoil heaps have 
generally a higher content of coal, and hence have a greater susceptibility to combustion. The exothermic reaction of pyrite with oxygen and water may ignite the coal tip, and the relatively easy circulation of air and water is enhanced by the poor compaction of the spoil heap (Harrington and East, 1949; Monjoie and Schroeder, 2001).

The surface of a burning coal tip has a temperature between $25^{\circ} \mathrm{C}$ and $60^{\circ} \mathrm{C}$, and this can reach $>100^{\circ} \mathrm{C}$ at a few dm depth and $>1000^{\circ} \mathrm{C}$ in the inner part of the tip. The areas where there is burning have a sparse grass vegetation (trees are absent) and are free of snow in winter (Debehault, 1968; Frankard, 2000; Monjoie and Schroeder, 2001; Carpentier et al., 2005).

The combustion process will continue as long as coal is present to be burnt, a process that may take more than 50 years for a tip. Burning is observed especially near the highest point of the tip because the heat originating from the interior moves towards the apex of the spoil heap (Debehault, 1968; Frankard, 2000). Our observations from profile pits excavated in burnt areas show furthermore that the preferential orientation of shale debris in the spoil heaps is parallel to the surface, which enhances the transfer of heat from the inner to the tip.

\section{Materials and methods}

\subsection{Data collection}

Fieldwork took place between August 2008 and April 2009. The five spoil heaps were subdivided in 10-22 homogeneous land units, especially with regard to slope gradient, vegetation cover and slope aspect. The land units were mapped in the field using a GPS, and within each land unit a qualitative description was done, as well as quantitative and qualitative observations of potential factors of instability (Table 2), the findings of which were eventually organised in pre-defined classes. On the other hand the degree of expression of the different slope processes observed per land unit (see section 4.2) was recorded on an ordinal scale (no - few - much - very much).

*** Table 2 approximately here $* * *$

Digital terrain models (DTMs) with a resolution of $20 \mathrm{~m}$ were obtained from the Belgian National Geographic Institute (NGI, 2010a), and had been realised in 2007 (Petite Bacnure, Hasard, and Waterschei) and 2008 (Boubier and Héribus). In ArcView GIS 3.2, slope gradients and aspects were derived from the DTMs and contour lines developed. The latter corresponded well to the contour lines on the published topographical maps (NGI, 2010b). All GIS work was done in the Lambert '72 Belgian Datum (BD72).

\subsection{Data processing \\ 3.2.1. Mapping}

Homogeneous land units were mapped as polygons in ArcView GIS 3.2 thematic layers. Thematic maps were prepared by assigning values (average of the observed class) recorded in the field, to each polygon. The land units were then subdivided in pixels corresponding to those of the DTM. In all thematic layers, weighted averages were calculated for pixels that were part of two or three land units. 


\subsubsection{Statistical analysis}

After preparation of thematic layers, correlations and regressions were prepared between the causal factors and the intensity of the geomorphic processes. Layers representing topographical parameters, stoniness and vegetation cover held quantitative data that could directly be used in statistical analyses. However, the layers that were related to soil texture classes and direct human impact (garbage dumping and motor sports activities) had nominal scales on which no mathematic calculations could be done; they were not used in the statistical analyses.

Other qualitative data on slope processes and combustion had an ordinal character. In assigning them numeric values ( 0 for absence of process, 1 for slight expression, 2 for strong and 3 for very strong expression), and assuming equal-appearing intervals (Thurstone, 1928), the ordinal scale was promoted to a quantitative interval scale, allowing us to involve the thematic layers regarding slope processes in statistical analyses.

The strength of the relations between variables was measured with the Pearsoncorrelation coefficient $r$. The significance of these coefficients was tested at different probability levels $(p)$ by F-tests (Beguin, 1979). To avoid multicollinearity in multiple regressions, correlation matrices were established between the independent variables.

Pole diagrams allowed a visual representation of the association between aspect and slope processes. As relations involving slope aspect do not follow a linear but a sinusoidal function, these relations were fitted to the model by Nyssen et al. (2005)

$$
y=s_{1}+s_{2}\left(\sin \left(x-s_{3}\right)\right)
$$

where $y=$ expected expression of slope process (scale of 0 to 3 ), $x=$ slope aspect (in degrees, turning right from the $\mathrm{N}$ ), and $\mathrm{s}_{1}$ to $\mathrm{s}_{3}$ are constants: $\mathrm{s}_{1}=$ expected average expression of the slope process, $s_{2}=$ amplitude of the sinusoidal function, and $s_{3}=$ aspect (in degrees) where the average expression of the slope process is expected.

Multiple regressions were used to explain the intensity of slope processes using several explanatory variables. The function had a sinusoidal component to represent the slope aspect and was linear for the other variables (Nyssen et al., 2005); stepwise models were created, at each step leaving out the least significant explanatory variable (Beguin, 1979).

\section{Results}

4.1. Correlations between explanatory factors

In order to correctly carry out the analysis of the factors that influence the intensity of occurring slope processes, it is important to know how the explanatory factors are interrelated. As an example, the correlation matrix of Petite Bacnure is highlighted (Table 3 ) while stressing also salient features observed on other coal tips. Full quantitative data of this study are presented by Vermeersch (2009).

There is a relatively strong correlation $(r=0.60 ; p<0.01$, like all correlations presented in this section) between slope aspect and stone cover, with high stone cover on slopes oriented to the East. Aspect is also correlated to tree cover $(r=0.43)$. Overall, we found 
(often strong) correlations between tree cover and aspect, with highest tree cover on the northern slopes, except at the Hasard coal tip. On the Waterschei coal tip, the only one in our dataset that is not affected by combustion, $r=0.69$ and highest tree cover occurs on slopes with W, NW, N and NE aspect.

$* * *$ Table 3 approximately here $* * *$

The combustion is correlated to slope aspect ( $r=0.52$; Table 3$)$ and occurs preferentially on south-eastern slopes. There is a negative correlation $(r=-0.41)$ between rock fragment cover and size as well as between rock fragment cover and grass cover $(r=$ -0.43 ) and a strongly positive correlation between rock fragment size and total vegetation cover $(r=0.82)$.

At Petite Bacnure, we found a strong negative correlation $(r=-0.73)$ between grass and tree cover (Fig. 5A,C), and a positive correlation $(r=0.63)$ between combustion and grass cover (Fig. 5A,B). Finally, there is a negative correlation $(r=-0.61)$ between tree cover and combustion (Table 3 ). Such a negative correlation is found on all coal tips that burn or have burnt.

*** Figure 5 approximately here $* * *$

\section{2. $\quad$ Slope processes observed on the coal tips and their causal factors}

Active slope processes can be observed on all spoil heaps, at densities which are uncommon in north-western Europe with its generally undulating landscapes, low slope gradients and otherwise dense vegetation cover. The correlation table (Table 4) between dependent variables (slope processes) and causal factors shows strong correlations between slope aspect and the intensity of most processes. This is a constant on all spoil heaps. Yet it is important to also consider the dominant slope aspects at which the different processes take place at the different spoil heaps. On the other hand, weak correlations between slope process intensity and slope gradient are found on most spoil heaps. Correlations with rock fragment size are weak at Petite Bacnure but not at other spoil heaps. Throughout this section, the case of Petite Bacnure spoil heap will be particularly illustrated, as well as similarities or differences with other spoil heaps.

*** Table 4 approximately here ***

\subsubsection{Soil creep}

The constant, slow mass movement called soil creep is permanently present on coal tip slopes as a consequence of slope steepness and poor compaction. It is particularly recognized by the gravitropic bending of trees on many slopes of the spoil heaps. As this gravitropic bending of trees was used to determine the magnitude of creep, the process could not be observed in areas with low tree cover; a minimum of $30 \%$ tree cover was deemed necessary to have a sufficient sample of trees.

At Petite Bacnure, there is a strong correlation $(r=0.78 ; p<0.01$, like all correlations presented in this section 4.2) between intensity of creep and slope aspect (Table 4). Most creep occurs on the northern slopes of the spoil heap. This is in parallel with the strong positive correlation $(r=0.64)$ between creep and tree cover (Table 4$)$. The occurrence of creep on burnt areas is difficult to establish because burning areas have only trees at their margins. 


\subsubsection{Sheet erosion}

The occurrence of sheet erosion could particularly be recognised by root denudation of the shallow rooted birch trees. Sheet erosion depths of $5 \mathrm{~cm}$ are common, but there is also a large spatial variability in erosion depth.

With regard to the factors of sheet erosion at Petite Bacnure, there is a correlation ( $r=$ 0.51 ) between sheet erosion and slope aspect (Table 4). Sheet erosion particularly occurs on north-oriented slopes. At the same spoil heap, there is a strong negative correlation ( $r$ $=-0.65$ ) between sheet erosion and grass cover (Table 4, Fig. 5A,D). Given the strong negative correlation between grass and tree cover (Table 3, Fig. 5A,C), there is expectedly also a positive correlation $(r=0.62)$ between sheet erosion and tree cover (Table 4). Sheet erosion intensity is also negatively correlated to grass cover on most other spoil heaps. Last but not least, at Petite Bacnure, there is a strong negative relation $(r=-0.62$ ) between sheet erosion and combustion (Table 4, Fig. 5B,D), which was also observed at the other burning coal tips.

$* * *$ Figure 6 approximately here $* * *$

\subsubsection{Rill erosion}

Rills are linear incisions by water erosion and are distinguished from gullies by a critical cross-section of one square foot $\left(930 \mathrm{~cm}^{2}\right.$; Poesen et al., 1996). On coal tips, they occur frequently in areas void of vegetation, particularly in minor depressions (Fig. 6). As the rills are not obliterated by cultivation, spoil heaps contain areas with the most spectacular rill densities of the wide surroundings.

There is a strong correlation between rill erosion and slope aspect $(r=0.75)$ at Petite Bacnure (Table 4), whereby rill erosion mainly occurs on slopes with northern to southeastern aspects. Further, there is a consistent negative relation of rill erosion with tree cover on all spoil heaps (Table 5).

*** Table 5 approximately here $* * *$

\subsubsection{Gully erosion}

Gullies have been defined as recently developed drainage lines of ephemeral streams with steep banks and a nearly vertical gully head (Poesen et al., 2003). At most spoil heaps there are strong correlations between gully erosion volumes and slope aspect. At Petite Bacnure $(r=0.80)$, gully erosion has limited dimensions and occurs especially on the north-eastern slopes.

\subsubsection{Landsliding}

We have observed landslides on all spoil heaps, and, except in Waterschei, all were related to areas under combustion. Landslide scars were observed at the very location of combustion at Petite Bacnure, Hasard and Héribus. The area affected by landsliding includes also the tongue which generally extends well downslope of the combustion area. For this reason, we found no strong correlation between landsliding and area of combustion. At Petite Bacnure, like on other spoil heaps, there is a correlation $(r=0.40)$ between landsliding and grass cover (Table 4), and a fairly strong negative correlation $(r$ $=-0.57$ ) between landsliding and tree cover (Table 4). The latter is also the case on other spoil heaps, except in Waterschei. 


\subsubsection{Rock fragment movement over the slopes}

Rolling and sliding of rock fragments is common on all spoil heaps. The movement is evidenced by the accumulation of large rock fragments in depressions and at the foot of the coal tips. Particularly, if not embedded, or covered by leaves or vegetation the movement is deemed to have taken place at a later stage after spoil dumping. Advent of larger rock fragments in adjacent gardens is reported by neighbours and was studied in detail by Corexenos (2001). At Petite Bacnure, like on most spoil heaps, the most significant observed factor of instability for rock fragment movement is slope aspect ( $r=$ $0.44)$, a western aspect in this case.

\subsubsection{Deposition and formation of debris cones}

Deposition evidences the active slope processes that take place on the spoil heaps.

There is a strong correlation (Table 4), at Petite Bacnure, between deposition and slope aspect $(r=0.60)$, with most deposition on slopes oriented to south and south-west. This is particularly the case at Waterschei $(r=0.76)$ and to a lesser extent at the other studied coal tips.

\subsubsection{Root throw}

Toppled trees are surprisingly common in the young forests on coal tips. Root throw, i.e. displacement of soil attached to roots in down slope direction is a slope process that is not negligible on coal tips. At Petite Bacnure, with relatively high tree cover in many places, there are no correlations (with $r>0.40$ ) between causal variables and root throw density (Table 4). Here, exceptionally, root throw occurs only at two locations which are located at the foot of the spoil heap. Generally, no favourable slope aspects for root throw could be found on the spoil heaps.

\section{Discussion}

The sometimes strong correlations that exist between phenomena must be critically taken into account. There is strong anthropogenic, but non predictable, direct impact: there are no data on the distribution of the different kinds of debris within the coal tips at the moment of dumping. Hence, the location where processes occur is more difficult to foresee than on natural materials. Parts with high coal content will easily be subjected to burning, and the variability of rock fragment content, cover and size of the top soil may impact the magnitude of slope processes. On the other hand, tree cover is also partly induced by forestation programmes of the 1950s-1960s (Masson, 1950) that took place to stabilize slope sections, and hence not entirely determined by natural conditions only. The case of the Petite Bacnure coal tip (Fig. 5B,C) illustrates such interactions. Due to high coal content, the southern slopes tend to burn which has led to absence of trees. Both phenomena are strongly correlated to slope aspect, but neither of them can be related to intensity of climatic factors that are generally associated with aspect.

\subsection{Variability in geomorphic processes on the studied coal tips \\ 5.1.1. Soil creep on humid slopes}

The comparison of the five studied coal tips in Belgium suggests that the intensity of creep is strongly correlated with slope aspect, and it occurs mostly on slopes exposed to the north-west. It is also often positively correlated with tree cover. Dominance of soil 
creep on north-westerly slopes is explained by the combination of rainy winds that come from westerly direction and shadow effect on the northern slopes, which leads to greater moisture content and enhanced creep.

Stepwise developed multiple regressions for creep, including the most significant explanatory variables, typically take either of the following formats:

$C R=-0.93+0.02 R F S+0.03 T C\left(r^{2}=0.46 ; p<0.0001 ; n=309\right)$

at the spoil heap of Petite Bacnure, where $C R=$ expression of creep movement (dimensionless, scale of 0 to 3), RFS = rock fragment size (in $\mathrm{cm}$ ), and $T C=$ tree cover (in \%), or:

$C R=1.27+0.14 \sin (0.0168 S A+4.18)-0.21 R F S\left(r^{2}=0.46 ; p<0.0001 ; n=430\right)$

at the spoil heap of Hasard, where $S A=$ slope aspect (in degrees, turning right from the north).

For all studied coal tips, the causal factor 'rock fragment size' appears most frequently in the multiple regression equations (mostly positively correlated), followed by 'tree cover' (positively correlated), 'slope aspect', 'slope gradient' (negatively correlated) and 'rock fragment cover' (negatively correlated).

\subsubsection{Sheet erosion on windward slopes}

On all studied spoil heaps, sheet erosion intensity is related to slope aspect: on northern slopes at Petite Bacnure, on western slopes at Boubier, on north-western at Waterschei, on south-western at Hasard and southern at Héribus. Besides local effects of other variables, the dominance of sheet erosion on westerly slopes can be directly related to the greater rain volumes that these slopes receive, due to dominant wind directions.

A generally negative effect of combustion on sheet erosion intensity was found, which is related to several of the effects of combustion, such as winter grass growth, evaporation and hence less runoff, as well as greater porosity due to pseudokarst effects in which burnt coal is replaced by voids that enhance infiltration.

The multiple regression equations for the various spoil heaps mostly include slope aspect and commonly also rock fragment cover and size as well as grass cover (all negatively correlated); these equations often have strong correlation coefficients ( $r^{2}$ between 0.32 and 0.87$)$.

\subsubsection{Rill erosion: role of slope aspect and shallow roots}

Except for the Hasard spoil heap, rill erosion is strongly correlated to slope aspect (Table 5). On the Waterschei and Héribus coal tips most rill erosion occurs on the south- and north-westerly slopes respectively, which may be directly explained by the dominant direction of rainy winds. Against expectation, most rill erosion on Petite Bacnure and Boubier occurs on eastern slopes. Rill erosion density is of course also directly and negatively related to vegetation density, to grass cover, but particularly to tree cover. The impeding effect of shallow birch roots on rill erosion must be stressed here. 
In the multiple regressions for rill erosion on our five spoil heaps, a weak to moderate correlation ( $r^{2}$ between 0.18 and 0.57$)$ was found. The explanatory factor 'total vegetation' (negatively correlated) was generally part of the significant factors, as well as tree cover (negatively correlated) and grass cover (sometimes negatively correlated).

\subsubsection{Gully erosion}

Except for Héribus, gully erosion on the spoil heaps is correlated to slope aspect, generally a southern aspect (Petite Bacnure and Hasard: eastern aspect), which is to be related to the dominant direction of rainy winds and hence greater rainfall and runoff. In addition, trees, which commonly impede gully erosion, have less density on southern slopes. Gully erosion is strongly correlated to rock fragment cover (almost always positively) and moderately to tree cover (mostly negatively).

The multiple regressions for gully erosion on the five coal tips $\left(r^{2}\right.$ between 0.13 and 0.71 ), generally comprised rock fragment cover (mostly positively correlated), and often slope aspect, tree cover (negatively correlated) and combustion (negatively correlated). Gullies occur especially on the Héribus mine spoil which is flat-topped and hence has a larger catchment that provides sufficient runoff volumes to enhance gully formation, as also shown by Palmers (1995). Generally, gullies are related to specific topographic features (size and shape of drainage areas). They are located in depressions, but also along preferential flow paths such as footpaths or motor cross tracks. Gullies on mine spoils in Belgium do however not reach spectacular volumes like ephemeral gullies in the European loam belt (Nachtergaele and Poesen, 1999) or valley bottom gullies in Ethiopia (Nyssen et al., 2006b).

\subsubsection{Landsliding, as induced by combustion}

Landslides are the most spectacular slope processes on coal tips. The correlation between slope aspect and landsliding is strongest at the Waterschei spoil heap. Here, the occurrence of several small debris slides is not related to burning and landsliding expectedly occurs on the relatively humid north-western slopes which have high rainfall and are less exposed to sunshine. On this spoil heap, landsliding is also positively correlated to tree cover $(r=0.65 ; p<0.01)$; the better growth of birches on these humid slopes does not impede sliding due to its shallow root depth.

Whereas landsliding was frequent in the period of dumping and has led to catastrophes (McLean and Johnes, 2000), the current landsliding is part of the stabilisation process and is mostly correlated to combustion (Petite Bacnure, Hasard, Héribus) (see section 2.6.5). Besides pseudokarstic phenomena (decrease of mass and local collapse due to combustion), there is a major effect of rain water infiltration, subsequent evaporation and creation of vapour pressure (Carpentier et al., 2005; Nyssen et al., 2010), which, combined with humidity and slope steepness, triggers landsliding.

Also the negative correlation between landsliding and tree cover on burning coal tips is well understood: tree vegetation cannot exist on locations subject to burning.

These findings correspond to the results of the multiple regressions for landsliding $\left(r^{2}\right.$ between 0.10 and 0.52 ). These were done for four spoil heaps, because on the Boubier spoil heap no landsliding was observed. 

are at the surface

Generally, and logically, rock fragment movement is positively correlated to rock fragment cover and to rock fragment size, which in its turn is correlated to the impact of gravity. There is also, on all coal tips, a positive but weak correlation with slope gradient, which is explained by the uniform slope gradients that exist on spoil heaps (generally between $20^{\circ}$ and $30^{\circ}$ ).

Both rock fragment mass and slope gradient will contribute to overcome resistance by friction (Bozzolo and Pamini, 1986; Erismann and Abele, 2001; Nyssen et al., 2006a). Triggers may be runoff, occasional shepherding, walking and wildlife.

The multiple regressions for rock fragment movement on the studied spoil heaps show a weak to moderate correlation $\left(r^{2}\right.$ between 0.10 and 0.63 ). Rock fragment size (almost always positively correlated) is an explanatory factor in all multiple regressions and rock fragment cover is another factor that is often part of the regression (mostly positively correlated).

\subsubsection{Sediment deposition at the foot of windward slopes}

Debris cones exist particularly at the foot of steep slopes with poor vegetation cover, at the outlet of the minor valleys in between ridges created at the time of shedding, and as local deposits at the upper side of tree trunks and metallic waste that was left behind during dumping. Except for Héribus, on all coal tips there is a moderate to good correlation between slope aspect and deposition, with most slope deposits on the southwestern slopes (Boubier: eastern slopes). As expected, overall the highest intensity of slope processes takes place at the same aspect where deposition occurs (Table 6). Preferential deposition on the south-western slopes may obviously be related with the dominant direction of rainy winds in Belgium; higher rain leads to intenser slope processes.

Not all multiple regressions for deposition yield strong correlations $\left(r^{2}\right.$ varies between 0.21 and 1.00). Here, rock fragment cover (mostly positively correlated) is the most frequently explanatory factor. Other variables that appear several times are rock fragment size (sometimes positively correlated) and total vegetation (negatively correlated). Basically, the deposition should be seen as integrating the sediment produced by the various slope processes.

*** Table 6 approximately here $* * *$

5.1.8. Root throw where the debris is void of large rock fragments Steep slopes, shallow rooting of birches and looseness as well as poor structure of the materials of the spoil heaps are evident causes of tree toppling. Except at Waterschei, root throw is positively correlated with tree density. Further, the negative correlation between root throw and rock fragment size is related to the fact that coal tip slopes composed of fine material provide less possibilities for root anchorage, leading to easier toppling (Danjon and Reubens, 2008).

Only, at Waterschei (south slopes) and Boubier (north slopes), root throw is correlated to slope aspect - again these are the aspects with greatest tree densities. Similarly, the negative correlations of root throw with combustion are easily explained by the fact that on burning places no trees grow and hence no root throw can take place. 
The multiple regression equations for root throw ( $r^{2}$ between 0.18 and 0.54 ) almost always comprise tree cover (mostly positively correlated) and mostly grass cover (negatively correlated), and only once slope gradient, rock fragment cover and combustion (all negatively correlated).

\subsection{General tendencies in geomorphic activity}

The expression of erosion and deposition is strongly determined by slope aspect (Fig. 7). Generally, most intense slope processes take place on slopes with a western aspect (Table 6) whereas deposition occurs on south and south-western slopes. Two major reasons are that some aspects are more exposed to rain and wind, especially in periods with intense rainfall, and the terrain is unusually steep $\left(>20^{\circ}\right)$. The geometrical equation of Fourcade (1942) and Blocken et al. (2006):

$P^{*}=P(1+\tan \alpha \tan \beta \cos (\gamma-\delta))$

where: $P^{*}=$ hydrological rainfall actually intercepted on the ground $(\mathrm{mm}), P=$ conventionally measured rainfall $(\mathrm{mm}), \alpha=$ local inclination of the ground surface relative to the horizontal, $\beta=$ rainfall obliquity relative to the vertical, $\gamma=$ slope aspect of the ground surface, and $\delta=$ direction from which the rain is coming, was used with some rain obliquities measured in Belgium (Poesen, 1986). The result shows for instance that on a modal spoil heap slope of $25^{\circ}$, for $100 \mathrm{~mm}$ of $P$ with a westerly direction and an obliquity of $7^{\circ}, 106 \mathrm{~mm}$ of $P^{*}$ is received on a slope with western aspect, $104 \mathrm{~mm}$ for south-western aspect and $94 \mathrm{~mm}$ for an eastern aspect. For rain with an obliquity of $42^{\circ}$, this becomes $142 \mathrm{~mm}$ for western, $130 \mathrm{~mm}$ for southwestern and $58 \mathrm{~mm}$ for slopes with eastern aspect, or merely $41 \%$ of what is received of slopes with western aspect.

*** Figure 7 approximately here $* * *$

Vegetation, another parameter which strongly interferes with slope processes, is largely determined by slope aspect, as that determines intercepted rainfall and angle of insulation. The effect of slope aspect is also artificial as it does not purely translate biophysical, climate-affected characteristics; the properties of a given slope segment depend also on the timing and characteristics of spoil dumping and on possible reforestation activities.

A second major point is that the intensity of the various slope processes on our coal tips shows generally a poor correlation with slope gradients. As stated earlier by Palmers (1995), this is explained by the uniformity of slope gradients on these loose tipped spoil heaps, that hold close to the angle of rest. As an example, on the Boubier spoil heap (Fig. 8 ), $57 \%$ of the area is occupied by slopes with gradients between $20^{\circ}$ and $30^{\circ}$.

*** Figure 8 approximately here ***

Further, as expected, the intensity of most slope processes is negatively correlated to grass cover, which is effective in protection from erosion. Tree cover on spoil heaps, on the other hand, impedes rill erosion, which may well be related to the shallow roots of the dominant birch trees. Whereas other stabilisation properties of birch have been studied in 
detail (Peltola et al., 2000; Campbell and Hawkins, 2003), its impeding effect on rill erosion seems not to have been researched.

On burning spots of spoil heaps, trees are absent and grass will not prevent such areas from sliding, rather it will enhance infiltration (Descheemaeker et al., 2009). It may thus contribute to steam development in the heaps' inner as well as to temporary soil saturation, two conditions that favour landsliding.

\subsection{Potential for further use of the developed methodology}

The method we used to analyse the expression and causal factors of geomorphic processes on mine spoils in Belgium may be used to study the importance of geomorphic processes elsewhere. As stated in the introduction of this paper, mine spoils present various types of hazards that were studied in many countries of the world.

Several particularities of geomorphic processes on mine spoils make the use of such methodology relevant: (1) mine spoils have a relatively simple topography, with generally straight slopes and often a conical shape, so that delineation of land units that take into account slope aspect is possible, (2) the materials composing mine spoils are relatively homogeneous, so that stratigraphical differentiation and variability in soil development cannot be used to explain variability in factors of instability such as slope gradient or poor vegetation cover, and (3) the major variability in materials, rock fragment size, is unpredictable and can only be known by field recording.

\section{Conclusions}

This study on five intact conical coal tips in Belgium allowed analysing a wide range of geomorphic processes. Due to absence of a predictable geophysical setting, the magnitude of the slope processes that occur on spoil heaps is only partly correlated to usually suspect biophysical factors. Intensity of soil creep is greater on slopes with northwestern aspect which are moister since they are on the windward side and have higher rainfall; they further receive only the evening sun and hence are also subject to less evaporation. On almost all spoil heaps, sheet erosion is negatively correlated to grass cover and positively to slope aspect, but there is no dominant slope aspect that would show a stronger occurrence of sheet erosion. Rill and gully erosion are impeded by trees (birch roots) and occur on southern slopes but also eastern slopes (Boubier and Petite Bacnure).

Within the spoil heap settlement process, debris sliding occurs, but it is not active like catastrophic landslides that have taken place on active dumping sites such as the Aberfan disaster in Wales in 1966 (McLean and Johnes, 2000) or the Jupille slide in Belgium in 1961 (Calembert and Dantinne, 1965). Minor debris sliding as part of the settlement process was observed in Waterschei, where it takes place especially on slopes with a northern aspect. On three other coal tips larger debris slides were induced by combustion that affects steep slopes. At these sites of combustion, other slope processes are of lesser magnitude; the enhancing effect of tree absence on runoff-induced processes is most probably annihilated by high evaporation rates, denser grass cover, and hence less runoff. Root throw is correlated to tree density. Because of the rarity of individual large trees on spoil heaps, toppled trees are located within forested slope segments. 
Except for the Boubier coal tip, most deposition takes place on SW-facing slopes which is obviously related to the dominant direction of (maritime) wind and to the preeminence of geomorphic processes on slopes with those aspects (Table 6).

The expression of slope processes on the studied coal tips is (1) strongly dependent on the westerly aspect of the slopes, (2) independent of slope gradient (which presents a narrow range), (3) impeded by grass cover, and (4) not fully predictable due to variability in type and age of spoil dumping.

The variety of geomorphic processes observed makes spoil heaps an interesting pedagogical site for both scholars and the broader public with a large interest towards these "archaeological" remnants of a major previous industrial activity. The methodology developed here may be replicated in geomorphic studies on spoil heaps in other regions of the world.

\section{Acknowledgements}

We wish to acknowledge Walthère Franssen (Herstal, Belgium), a former mine worker and coal tip conservation activist, who has risen our interest in geomorphic research on coal tips. Information and feedback were provided by four Belgian socio-cultural institutions involved in coal tip conservation: EspaceTerrils (Aiseau-Presles), MijnErfgoed (Genk), Blègny-Mine and Maison des Terrils (Saint-Nicolas). The following colleagues provided useful insights or participated in fieldwork: Miet Van den Eeckhaut, Amaury Frankl, Pavlos Corexenos, Jean Poesen and Stijn Diependaele. Useful remarks by two anonymous reviewers are gratefully acknowledged.

\section{References}

Beguin, H., 1979. Méthodes d'analyse géographique quantitative. Librairies Techniques, Paris, 283 pp.

Blègny-Mine, 2010. Domaine touristique de Blègny-Mine. http://www.blegnymine.be/.

Blocken, B., Poesen, J., Carmeliet, J., 2006. Impact of wind on the spatial distribution of rain over micro-scale topography: numerical modelling and experimental verification. Hydrological Processes 20, 345-368.

Boggs, G.S., Evans, K.G., Devonport, C.C., Moliere, D.R., Saynor, M.J., 2000. Assessing catchment-wide mining-related impacts on sediment movement in the Swift Creek catchment, Northern Territory, Australia, using GIS and landform-evolution modelling techniques. Journal of Environmental Management 59, 321-334.

Bozzolo, D., Pamini, R., 1986. Simulation of rock falls down a valley side. Acta Mechanica 63, 113-130.

Bradshaw, A.D., 1997. Restoration of mined lands - using natural processes. Ecological Engineering 8, 255-269.

Bradshaw, A.D., 2000. The use of natural processes in reclamation - advantages and difficulties. Landscape and Urban Planning 51, 89-100.

Brink, H.-J., 2005. The evolution of the North German Basin and the metamorphism of the lower crust. International Journal of Earth Sciences 94, 1103-1116.

Buczko, U., Gerke, H.H., 2005. Modeling two-dimensional water flow and bromide transport in a heterogeneous lignitic mine soil. Vadose Zone J 5, 14-26. 
Calembert, L., Dantinne, R., 1965. L'avalanche de cendres volantes survenue à Jupille (Liège) le 3 février 1961, Volume d'hommage au professeur F. Campus. VaillantCarmanne, Liège, pp. 41-57.

Campbell, K.A., Hawkins, C.D.B., 2003. Paper birch and lodgepole pine root reinforcement in coarse-, medium-, and fine-textured soils. Canadian Journal of Forest Research 33, 1580-1586.

Carpentier, O., Defer, D., Antczak, E., Duthoit, B., 2005. The use of infrared thermographic and GPS topographic surveys to monitor spontaneous combustion of coal tips. Appl. Thermal Eng. 25, 2677-2686.

Charlier, R.H., 2000. Land recovery: "brownfields" a viewpoint. International Journal of Environmental Studies 57, 283 - 292.

Corexenos, P., 2001. Détermination des risques que présentent les terrils. Le cas du terril de Bernalmont. Licentiate thesis, Université de Liège, Department of Geography.

Corne, H., De Keghel, P., 2006a. Sentier des Terrils. Topo-Guide du Sentier de Grande Randonnée. GR 412 Ouest. Borinage - Centre - Bassin de Charleroi. Les Sentiers de Grandes Randonneés ASBL.

Corne, H., De Keghel, P., 2006b. Sentier des Terrils. Topo-Guide du Sentier de Grande Randonnée. GR 412 Est. Namurois - Hesbaye - Bassin liégeois. Les Sentiers de Grande Randonnée ASBL.

Cornwell, S.M., 1971. Anthracite mining spoils in Pennsylvania. I. Spoil classification and plant cover studies. Journal of Applied Ecology 8, 401-409.

Danjon, F., Reubens, B., 2008. Assessing and analyzing 3D architecture of woody root systems, a review of methods and applications in tree and soil stability, resource acquisition and allocation. Plant and Soil 303, 1-34.

De Munck, C.S., Hutchings, T.R., Moffat, A.J., 2009. Impacts of climate change and establishing a vegetation cover on water erosion of contaminated spoils for two contrasting United Kingdom regional climates: A case study approach. Integrated Environmental Assessment and Management 4, 443-455.

De Roeck, M., Tilmont, J., 1971. Algemene Atlas. Ad. Wesmael-Charlier, Namen.

Debehault, C., 1968. Les terrils de charbonnage du Borinage. Etude de géographie régionale. Revue Belge de Géographie 92, 9-57.

Descheemaeker, K., Raes, D., Nyssen, J., Poesen, J., Mitiku Haile, Deckers, J., 2009. Changes in water flows and water productivity upon vegetation regeneration on degraded hillslopes in northern Ethiopia: a water balance modelling exercise. The Rangeland Journal 31, 237-249.

Detalle, F., 2006. Evaluation de risques que représente l'ancienne activité charbonnière; le cas du terril du Hasard à Retinne. Mémoire de Licence en Sciences géographiques. Université de Liège, Belgium.

DGARNE, 2010. Liste des terrils http://environnement.wallonie.be/cgi/dgrne/terrils/liste_old.idc. Ministère de la Région wallonne, Direction générale Opérationnelle de l'Agriculture, des Ressources naturelles et de l'Environnement, Namur, Belgium.

Erismann, T.H., Abele, G., 2001. Dynamics of Rockslides and Rockfalls. Springer, Berlin, $316 \mathrm{pp}$.

EspaceTerrils, 2008. La Chaîne des Terrils. (http://www.terrils.be/index.php, accessed on 8.1.2008). 
Evans, K.G., Saynor, M.J., Willgoose, G.R., Riley, S.J., 2000. Post-mining landform evolution modelling: 1. Derivation of sediment transport model and rainfallrunoff model parameters. Earth Surface Processes and Landforms 25, 743-763.

Evans, K.G., Willgoose, G.R., 2000. Post-mining landform evolution modelling: 2. Effects of vegetation and surface ripping. Earth Surface Processes and Landforms 25, 803-823.

Fourcade, H.G., 1942. Some notes on the effects of the incidence of rain on the distribution of rainfall over the surface of unlevel ground. Transactions of the Royal Society of South Africa 29, 235-254.

Fox, H.R., Moore, H.M., McIntosh, A.D., 1998. Land Reclamation Achieving Sustainable Benefits. Proc. 4th Intern. Conf. Intern. Association of Land Reclamationists, Nottingham, UK, 7-11 Sept 1998. Balkema, Dordrecht, 560 pp.

Frankard, P., 2000. Aperçu de la flore et de la végétation des terrils de la région liégeoise. Bulletin de la Société Royale des Sciences de Liège 69, 265-287.

Gerke, H.H., Hangen, E., Schaaf, W., Hüttl, R.F., 2001. Spatial variability of potential water repellency in a lignitic mine soil afforested with Pinus nigra. Geoderma $102,255-274$.

Goossens, D., 1984. Inleiding tot de geologie en geomorfologie van België. Geologische Boekhandel W.G. Witkam, Enschede.

Haigh, M.J., Sansom, B., 1999. Soil compaction, runoff and erosion on reclaimed coallands (UK). International Journal of Mining, Reclamation and Environment 13, $135-146$.

Haigh, M.J., Gentcheva-Kostadinova, S., 2002. Ecological erosion control on coal-spoil banks: an evaluation. Ecological Engineering 18, 371-377.

Hancock, G.R., Loch, R.J., Willgoose, G.R., 2003. The design of post-mining landscapes using geomorphic principles. Earth Surface Processes and Landforms 28, 10971110.

Hancock, G.R., Crawter, D., Fityus, S.G., Chandler, J., Wells, T., 2008. The measurement and modelling of rill erosion at angle of repose slopes in mine spoil. Earth Surface Processes and Landforms 33, 1006-1020

Hangen, E., Gerke, H.H., Schaaf, W., Hüttl, R.F., 2005. Assessment of preferential flow processes in a forest-reclaimed lignitic mine soil by multicell sampling of drainage water and three tracers. Journal of Hydrology 303, 16-37.

Harrington, D., East, J.H., 1949. Incendies des terris. Annales des Mines de Belgique XLVIII, 427-434.

Heempark, 2010. Mijnterrils van Genk http://www.heempark.be/content/hp_content/record.php?ID=62. Heempark milieu- en natuurcentrum, Genk, Belgium.

Hodačová, D., Prach, K., 2003. Spoil heaps from brown coal mining: technical reclamation versus spontaneous revegetation. Restoration Ecology 11, 385-391.

Hüttl, R.F., Heinkele, T., Wisniewski, J., 1996. Minesite Recultivation. Springer, 172 pp.

Jochimsen, M.E.A., 1996. Reclamation of colliery mine spoil founded on natural succession. Water, Air, \& Soil Pollution 91, 99-108.

Ledent, P., 1993. Méthode pour la télédétection satellitaire des terrils. Expérimentation sur la région liégeoise. Mémoire de Licence en Sciences géographiques Thesis, Université de Liège, Belgium, 162 pp. 
Lohest, M., Habets, A., Forir, H., 1904. La géologie \& la reconnaissance du terrain houiller du nord de la Belgique. Impr. H. Vaillant-Carmanne, Liège.

Loredo, J., Ordonez, A., Gallego, J.R., Baldo, C., Garcia-Iglesias, J., 1999. Geochemical characterisation of mercury mining spoil heaps in the area of Mieres (Asturias, northern Spain). Journal of Geochemical Exploration 67, 377-390.

Maison des Terrils, 2010. Pays des terrils, parcs paysagers. Maison des Terrils, St.Nicolas (Belgium), 22 pp.

Masson, J., 1950. Le boisement des terris houillers et autres déblais de carrières. Le Vieux-Liege 87.

McLean, I., Johnes, M., 2000. Aberfan: Disasters and Government. Welsh Academic Press, Cardiff.

Mijnerfgoed, 2008. Erfgoedcel Mijn-Erfgoed. http://www.erfgoedcelmijnerfgoed.be (Accessed 13.2.2008).

Minten, L., Raskin, L., Soete, A., Van Doorslaer, B., Verhees, F., 1992. Een eeuw steenkool in Limburg. Lannoo, Tielt, 280 pp.

Monjoie, A., Demeuldre, D., Schroeder, C., Willame, J., 1985. Problèmes de Géologie de l'Ingénieur intervenant dans la stabilité d'un terril en cours de remodelage. Colloque C.B.G.I., 82-91.

Monjoie, A., Schroeder, C., 2001. Instabilités de versants de terrils en relation avec l'autocombustion des schistes et charbons résiduels. Revue française de Géotechnique 95-96, 91-102.

Nachtergaele, J., Poesen, J., 1999. Assessment of soil losses by ephemeral gully erosion using high-altitude (stereo) aerial photographs. Earth Surface Processes and Landforms 24, 693-706.

NGI, 2010a. Digital Terrain Elevation Data of Belgium, 1/10 000. http://www.ngi.be/NL/NL1-5-5.shtm. National Geographic Institute, Brussels.

NGI, 2010b. Topographic maps of Belgium, 1/10 000. http://www.ngi.be/NL/NL1-11.shtm. National Geographic Institute, Brussels.

Nicolau, J.-M., 2002. Runoff generation and routing on artificial slopes in a Mediterranean-continental environment: the Teruel coalfield, Spain. Hydrological Processes 16, 631-647.

Nicolau, J.M., 2003. Trends in relief design and construction in opencast mining reclamation. Land Degradation \& Development 14, 215-226.

Nyssen, J., Vandenreyken, H., Poesen, J., Moeyersons, J., Deckers, J., Haile, M., Salles, C., Govers, G., 2005. Rainfall erosivity and variability in the Northern Ethiopian Highlands. Journal of Hydrology 311, 172-187.

Nyssen, J., Poesen, J., Moeyersons, J., Deckers, J., Haile, M., 2006a. Processes and rates of rock fragment displacement on cliffs and scree slopes in an amba landscape, Ethiopia. Geomorphology 81, 265-275.

Nyssen, J., Poesen, J., Veyret-Picot, M., Moeyersons, J., Mitiku Haile, Deckers, J., Dewit, J., Naudts, J., Kassa Teka, Govers, G., 2006b. Assessment of gully erosion rates through interviews and measurements: a case study from northern Ethiopia. Earth Surface Processes and Landforms 31, 167-185.

Nyssen, J., Diependaele, S., Goossens, R., 2010. Landslide susceptibility mapping on Belgium's burning coal tips using thermographic ASTER imagery and Digital Terrain Models. Earth Surface Processes and Landforms submitted. 
Paithankar, A.G., Jha, P.K., Agarwal, R.K., 2001. Geoenvironmental Reclamation: International Symposium, 20-22 November. Taylor \& Francis.

Palmers, J., 1995. Studie van de geul- en ravijnerosie op de Limburgse mijnterrils. Licentiate thesis Geography, K.U.Leuven, 129 pp.

Peltola, H., Kellomäki, S., Hassinen, A., Granander, M., 2000. Mechanical stability of Scots pine, Norway spruce and birch: an analysis of tree-pulling experiments in Finland. Forest Ecology and Management 135, 143-153.

Pissart, A., Macar, P., 1976. Géomorphologie de la Belgique. Université de Liège, 223 pp.

Poesen, J., 1986. Field measurements of splash erosion to validate a splash transport model. Z. Geomorphol. 58, 81-91.

Poesen, J.W., Vandaele, K., Van Wesemael, B., 1996. Contribution of gully erosion to sediment production on cultivated lands and rangelands. IAHS Publication 236, 251-266.

Poesen, J.W., van Wesemael, B., Bunte, K., Benet, A.S., 1998. Variation of rock fragment cover and size along semiarid hillslopes: a case-study from southeast Spain. Geomorphology 23, 323-335.

Poesen, J., Nachtergaele, J., Verstraeten, G., Valentin, C., 2003. Gully erosion and environmental change: importance and research needs. Catena 50, 91-133.

Raes, F., Bosteels, E., 2006. Terrils: De l'or noir à l'or vert Editions Racine, Bruxelles.

Rasmont, P., Barbier, Y., 2000. La faune des terrains industriels charbonniers. Bulletin de la Société Royale des Sciences de Liège 69, 289-307.

Renier, A., 1944. Quelques précisions sur la stratigraphie du terrain houiller de la Belgique. Mémoires du Musée royal d'Histoire naturelle de Belgique, 44, 101 pp.

Rovis-Hermann, J., Evans, K.G., Webb, A.L., Pidgeon, R.W.J., (eds), 2002. Environmental Research Institute of the Supervising Scientist Research Summary 1995-2000. Supervising Scientist Report 166.

Sanders, G., 2007. The Principles of Coal Preparation. Australian Coal Preparation Society, Hamilton, xvi, 539 pp.

Shepherd, R.G., 1989. Correlations of permeability and grain size. Ground Water 27, 633-638.

Taylor, R.K., Spears, D.A., 1972. The geotechnical characteristics of a spoil heap at Yorkshire Main Colliery. Quarterly Journal of Engineering Geology and Hydrogeology 5, 243-264.

Thurstone, L., 1928. Attitudes can be measured. American Journal of Sociology 33, 529554.

Urrutia, M., Garcia-Rodeja, E., Macias, F., 1992. Sulfide oxidation in coal-mine dumps: Laboratory measurement of acidifying potential with $\mathrm{H}_{2} \mathrm{O}_{2}$ and its application to characterize spoil materials. Environmental Management 16, 81-89.

Vermeersch, D., 2009. Geomorfologische dynamiek van het ecosysteem 'terril'. M.Sc. thesis, Department of Geography, Ghent University.

Willgoose, G., 1994. A physical explanation for an observed area-slope-elevation relationship for catchments with declining relief. Water Resour. Res. 30, 151-160.

Willgoose, G., Riley, S., 1998. Application of a catchment evolution model to the prediction of long-term erosion on the spoil heap at Ranger Uranium Mine, 107. Commonwealth of Australia, Australia. 
Willgoose, G., Sharmeen, S., 2006. A one-dimensional model for simulating armouring and erosion on hillslopes: 1. model development and event-scale dynamics. Earth Surface Processes and Landforms 31, 970-991.

Zodrow, E.L., 2005. Colliery and surface hazards through coal-pyrite oxidation (Pennsylvanian Sydney Coalfield, Nova Scotia, Canada). International Journal of Coal Geology 64, 145-155. 


\section{Figure captions}

Fig. 1. Location of the Belgian coal mines (status 1966) and of the five studied spoil heaps. 1) Héribus, 2) Boubier, 3) Petite Bacnure, 4) Hasard, 5) Waterschei (After De Roeck and Tilmont, 1971).

Fig. 2. View on the Boubier mine spoil, with birch trees (around $7 \mathrm{~m}$ high) for scale. North is to the right.

Fig. 3. Landslide at Petite Bacnure, as seen from the top of the spoil heap. The road between the circled house and the spoil heap has been obstructed by the landslide tongue (arrow) from 1999 till nowadays.

Fig. 4. Spring at the western foot of the Boubier coal tip, which is located at the back of the photograph. The circle is ca. $1 \mathrm{~m}$ across. Occurrence of springs on the foot of spoil heaps is a consequence of the high hydraulic conductivity in the spoil heap and then encounter of a relatively less pervious layer, which forces the water to flow out.

Fig. 5. Characteristics of the Petite Bacnure spoil heap, rasterised to the 20-m cells of the DTM (summit in the centre): (A) grass cover, (B) expression of combustion, (C) tree cover, (D) sheet erosion.

Fig. 6. Rill erosion on the Hasard coal tip. Note the absence of vegetation cover in the rilled area. Around 10-m high birch trees for scale.

Fig. 7. Average degree of expression (on a scale of 0 to 3 ) of different slope processes on the Waterschei spoil heap, by slope aspect. Note that the polar diagrams for gully erosion, landsliding and root throw bear different scales, because these slope processes were rated between 0 and 1 (none to few) only.

Fig. 8. Slope gradients on the Boubier coal tip. 


\section{Figures}

Figure 1

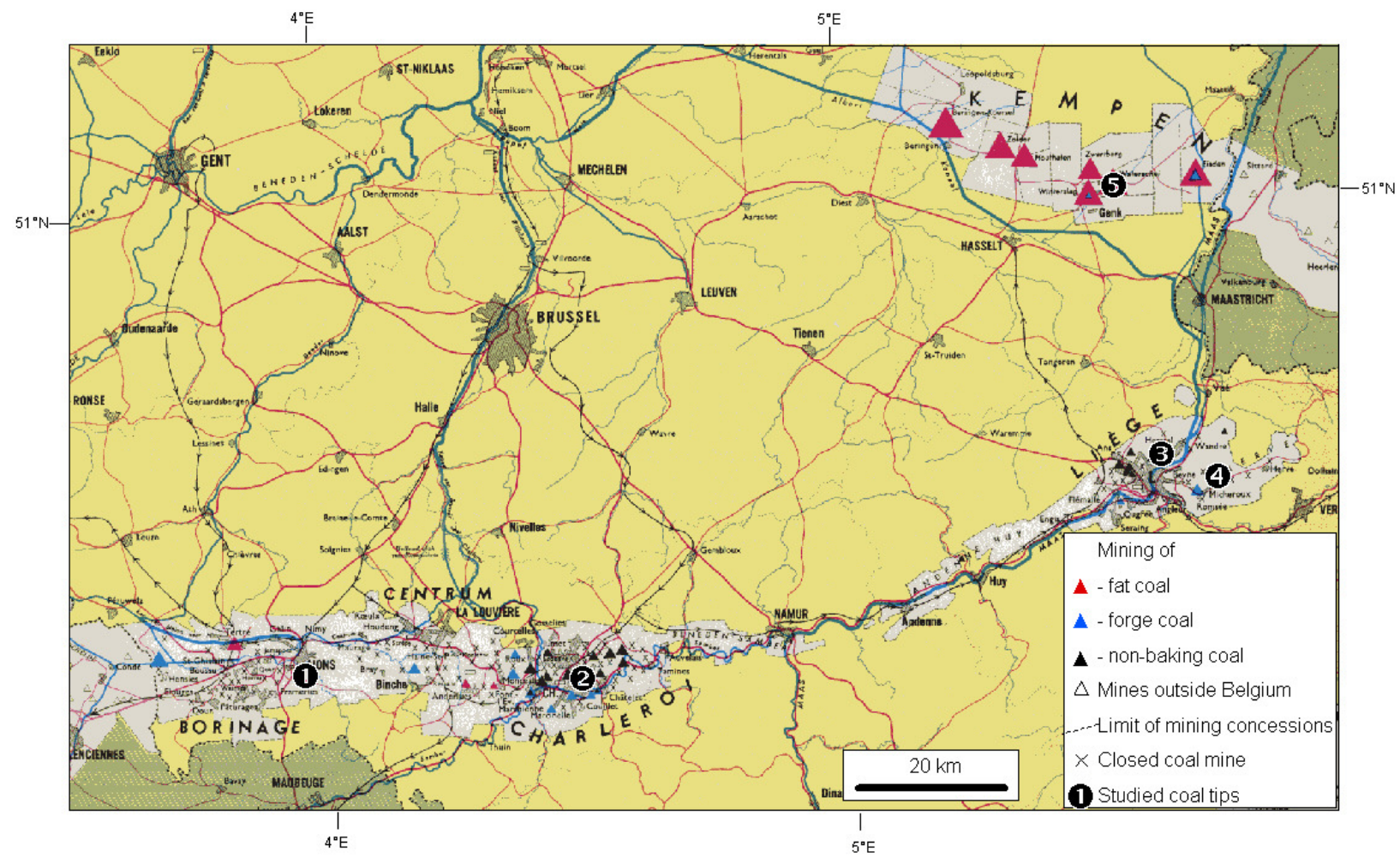

Figure 2

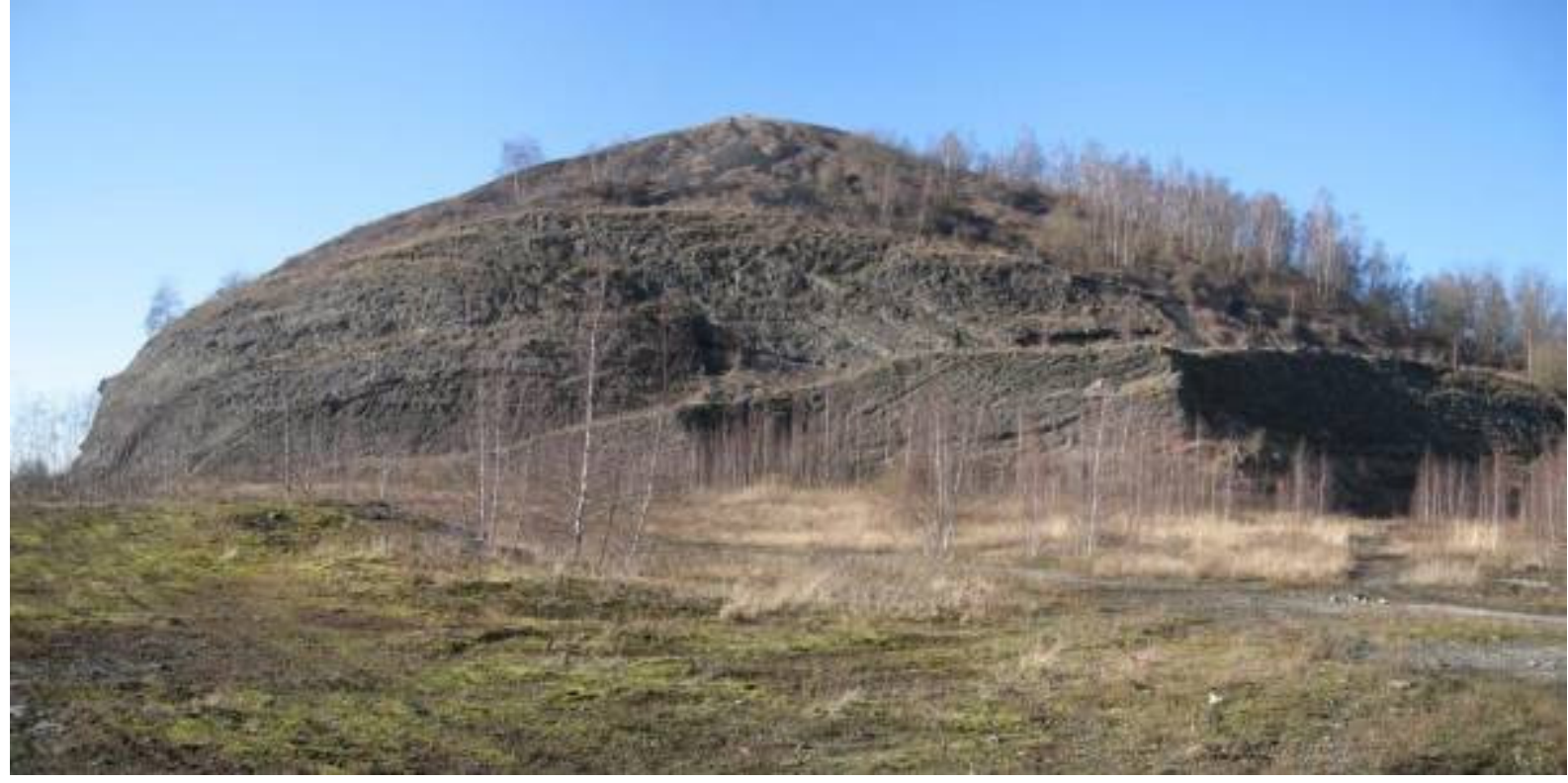


Figure 3.

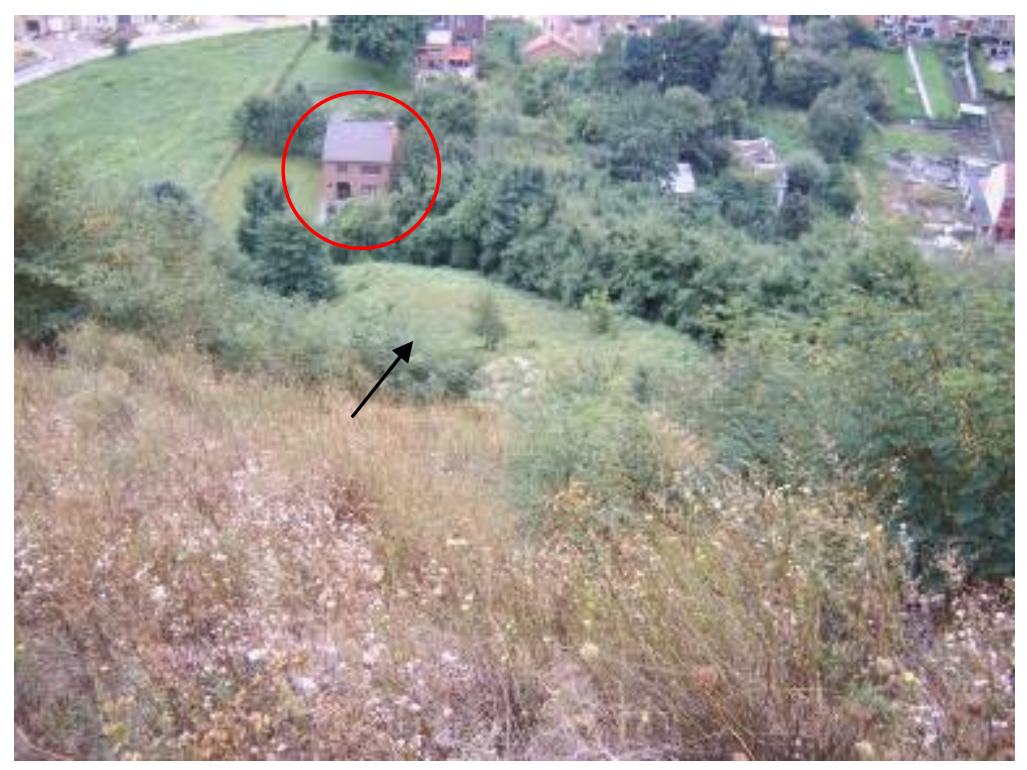

Figure 4.

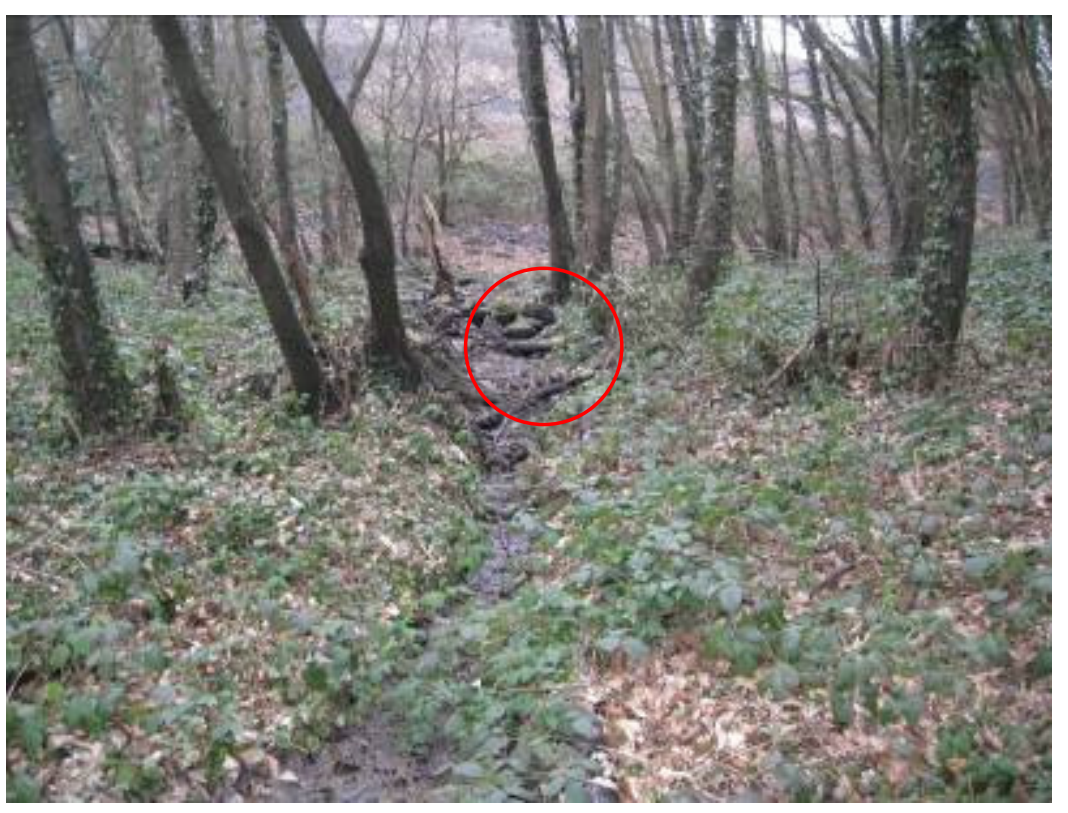


Figure 5

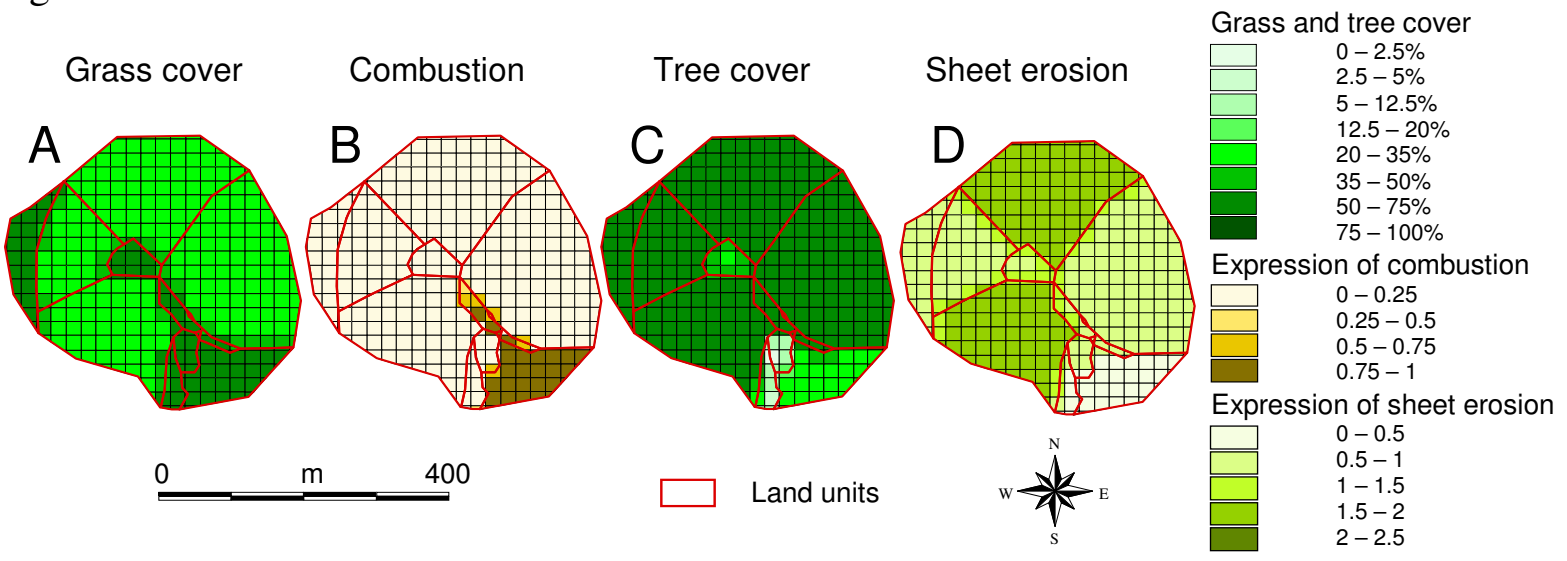

Figure 6.

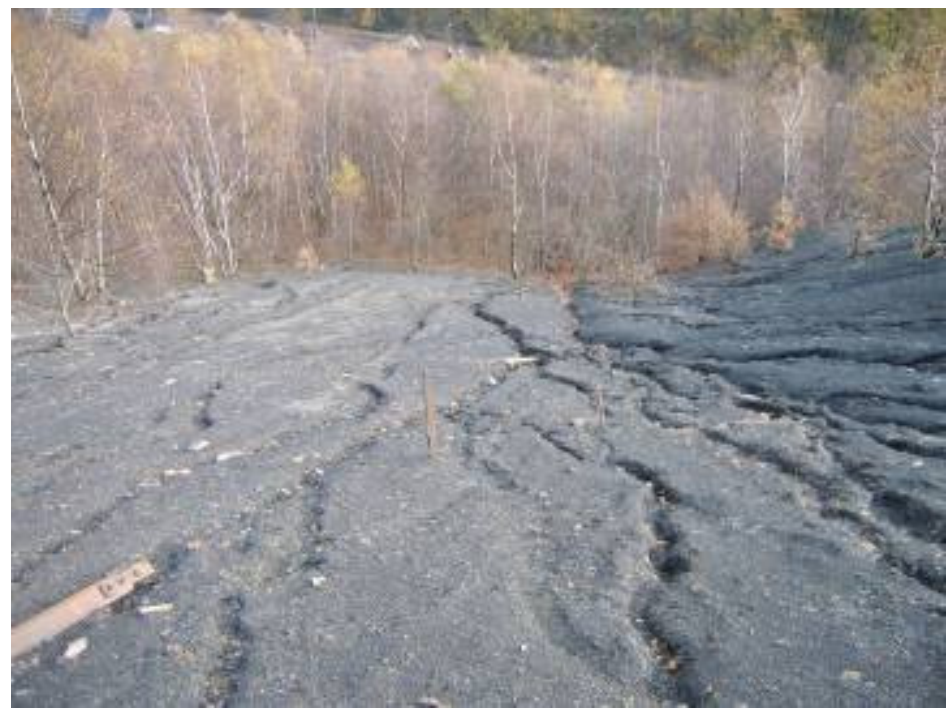


Figure 7

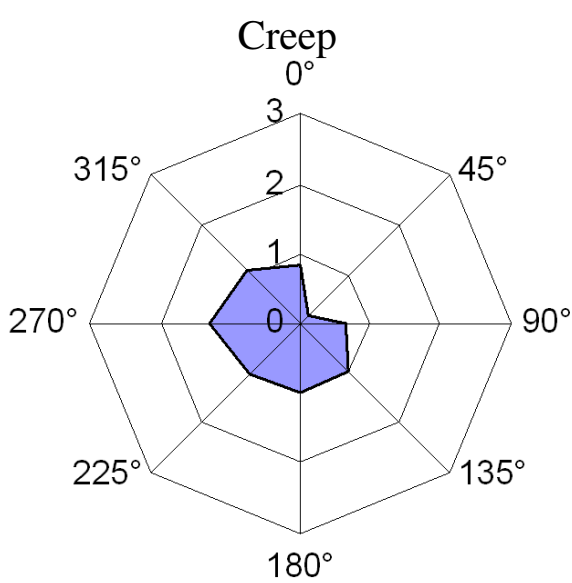

Landsliding

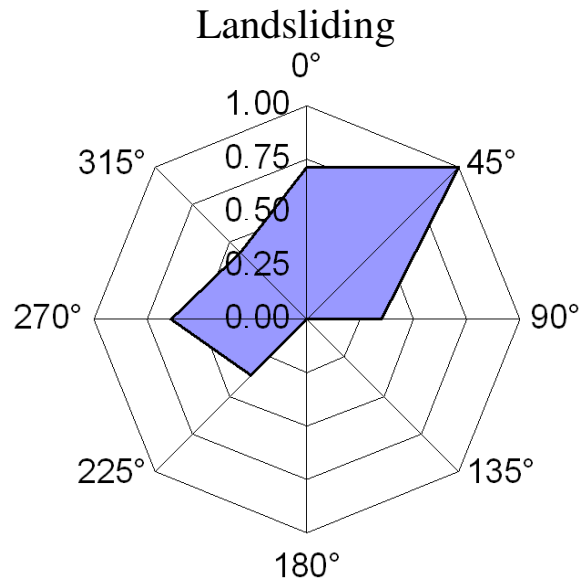

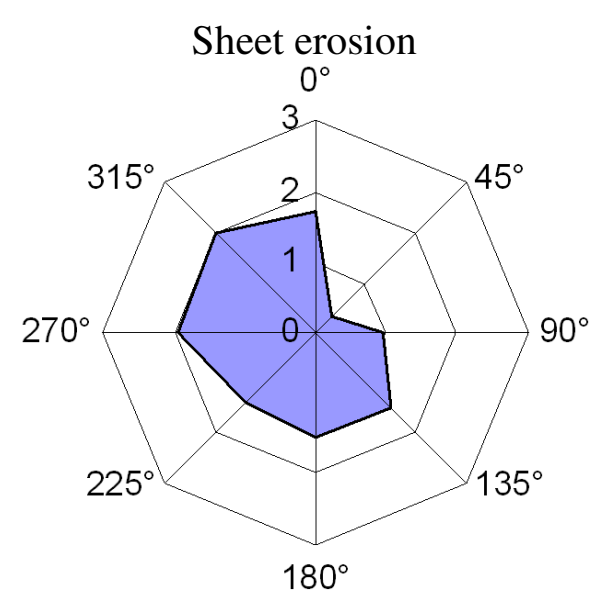

Rock fragment movement

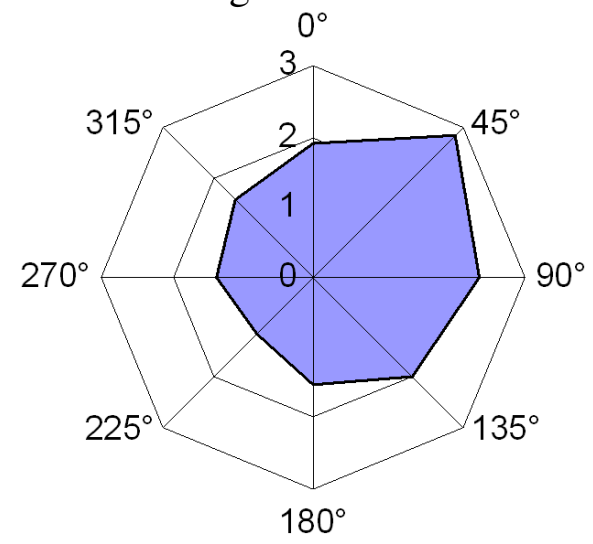

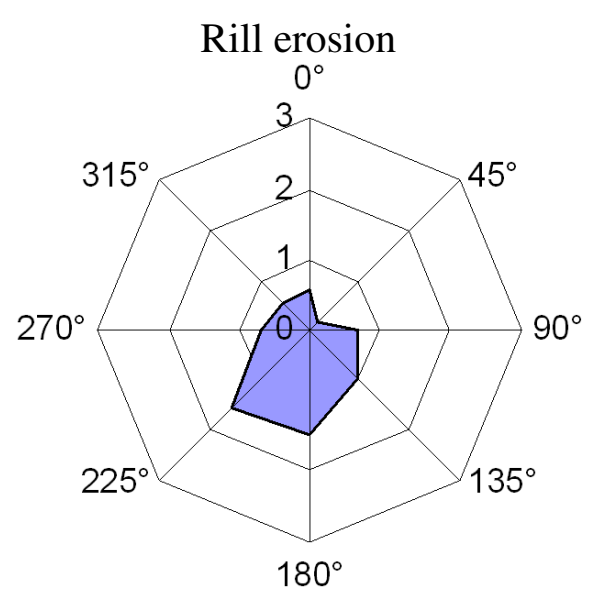

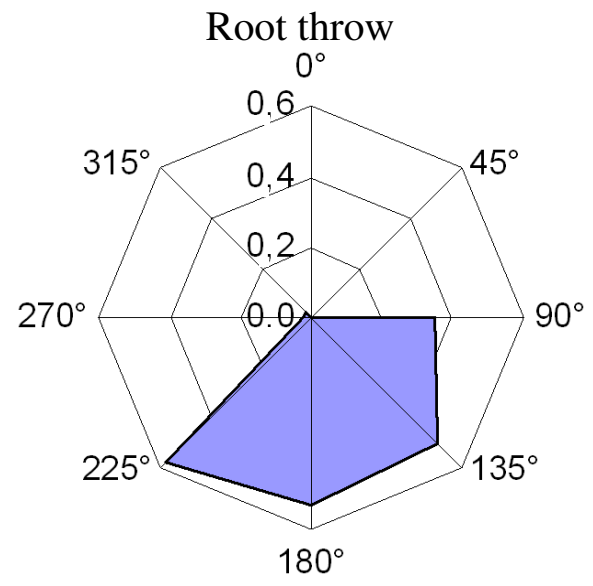

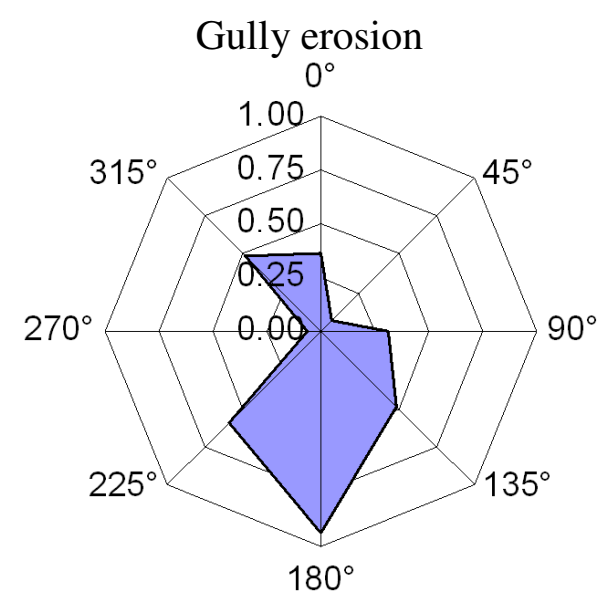

Sediment deposition

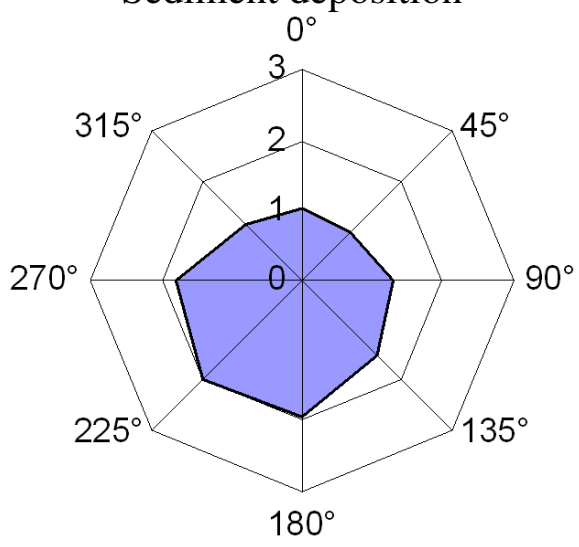


Figure 8

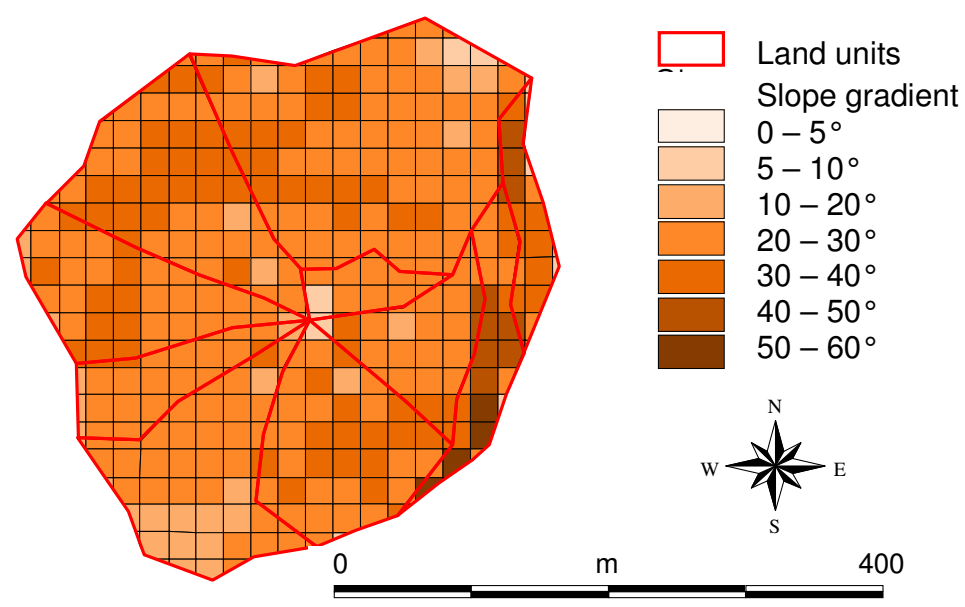




\section{Tables}

Table 1

Characteristics of studied spoil heaps

\begin{tabular}{|c|c|c|c|c|c|}
\hline & $\begin{array}{l}\text { Terril de } \\
\text { l'Héribus }\end{array}$ & $\begin{array}{l}\text { Terril du } \\
\text { Boubier }\end{array}$ & $\begin{array}{l}\text { Terril de la Petite } \\
\text { Bacnure }\end{array}$ & Terril du Hasard & $\begin{array}{l}\text { Terril van } \\
\text { Waterschei }\end{array}$ \\
\hline \multicolumn{6}{|l|}{ Location } \\
\hline Lat. $\mathrm{N}$ & $50^{\circ} 26^{\prime} 11^{\prime \prime}$ & $50^{\circ} 23^{\prime} 40^{\prime \prime}$ & $50^{\circ} 40^{\prime} 01^{\prime \prime}$ & $50^{\circ} 37^{\prime} 46^{\prime \prime}$ & $51^{\circ} 00^{\prime} 43^{\prime \prime}$ \\
\hline Lon. E & 3०56’22”' & $4^{\circ} 29 ’ 51^{\prime \prime}$ & 5॰36’28’' & 5॰42’29” & 532’32” \\
\hline \multicolumn{6}{|c|}{ Physical characteristics } \\
\hline Shape & $\begin{array}{l}\text { Conical with flat } \\
\text { top }\end{array}$ & Conical & $\begin{array}{l}\text { Conical with } \\
\text { mountain ridge }\end{array}$ & Conical & Conical \\
\hline Area (ha) & 18.24 & 13.50 & 10.66 & 15.78 & 7.91 \\
\hline Height (m) & 75 & 115 & 83 & 90 & 100 \\
\hline Volume $\left(\mathrm{m}^{3}\right)$ & 6000000 & 3750000 & 3231000 & 5300000 & Unknown \\
\hline $\begin{array}{l}\text { Absolute } \\
\text { height of top } \\
\text { (m a.s.l.) }\end{array}$ & 137 & 265 & 190 & 360 & 190 \\
\hline Combustion & $\begin{array}{l}\text { Combustion } \\
\text { stopped in the } \\
\text { period } 2001- \\
2010\end{array}$ & Not burned & Partially & Partially & Not burned \\
\hline \multicolumn{6}{|c|}{ Administrative characteristics } \\
\hline $\begin{array}{l}\text { Mine } \\
\text { concession } \\
\text { (last } \\
\text { situation) }\end{array}$ & $\begin{array}{l}\text { Produits and } \\
\text { Levant de Flénu }\end{array}$ & Boubier & $\begin{array}{l}\text { Grande Bacnure } \\
\text { and Petite } \\
\text { Bacnure }\end{array}$ & Hasard-Cheratte & Waterschei \\
\hline $\begin{array}{l}\text { Begin of spoil } \\
\text { deposition }\end{array}$ & 1919 & 1923 & Unknown & Unknown & 1953 \\
\hline $\begin{array}{l}\text { End of spoil } \\
\text { deposition }\end{array}$ & 1968 & 1966 & 1971 & 1971 & 1961 \\
\hline Remarks & $\begin{array}{l}\text { Two landslides } \\
\text { (at the west in } \\
1992 \text { and at the } \\
\text { east in 1994) }\end{array}$ & $\begin{array}{l}\text { Escarpment } \\
\text { at the east } \\
\text { side }\end{array}$ & $\begin{array}{l}\text { Landslide (1 April } \\
\text { 1999) }\end{array}$ & $\begin{array}{l}\text { Heighest coal tip } \\
\text { in Belgium, } \\
\text { panorama, } \\
\text { landslide (2002) }\end{array}$ & $\begin{array}{l}\text { Spoil heap } \\
\text { located on a } \\
\text { wider } \\
\text { platform, } \\
\text { paragliding } \\
\text { activivities }\end{array}$ \\
\hline \multicolumn{6}{|c|}{ Sources of information } \\
\hline $\begin{array}{l}\text { Topographic } \\
\text { map sheet } \\
(1 / 10000) \\
(\text { NGI, 2010b) }\end{array}$ & 45/7N Mons & $\begin{array}{l}46 / 8 \mathrm{~S} \\
\text { Charleroi }\end{array}$ & $\begin{array}{l}\text { 42/2S Liège } \\
\text { (Nord) }\end{array}$ & 42/7N Fléron & $\begin{array}{l}26 / 1 Z \\
\text { Waterschei }\end{array}$ \\
\hline Other sources & $\begin{array}{l}\text { (Monjoie and } \\
\text { Schroeder, 2001; } \\
\text { Corne and De } \\
\text { Keghel, 2006a; } \\
\text { EspaceTerrils, } \\
\text { 2008; DGARNE, } \\
\text { 2010) }\end{array}$ & $\begin{array}{l}\text { (Corne and } \\
\text { De Keghel, } \\
\text { 2006a; } \\
\text { DGARNE, } \\
\text { 2010) }\end{array}$ & $\begin{array}{l}\text { (Corexenos, 2001; } \\
\text { Monjoie and } \\
\text { Schroeder, 2001; } \\
\text { Corne and De } \\
\text { Keghel, 2006b; } \\
\text { EspaceTerrils, } \\
\text { 2008; DGARNE, } \\
\text { 2010) }\end{array}$ & $\begin{array}{l}\text { (Corne and De } \\
\text { Keghel, 2006b; } \\
\text { Detalle, 2006; } \\
\text { EspaceTerrils, } \\
\text { 2008; } \\
\text { DGARNE, } \\
\text { 2010) }\end{array}$ & $\begin{array}{l}\text { (Palmers, } \\
\text { 1995; } \\
\text { Heempark, } \\
\text { 2010) }\end{array}$ \\
\hline
\end{tabular}




\section{Table 2}

Field measurements done on the spoil heaps, at the scale of land units

\begin{tabular}{|c|c|c|c|}
\hline Parameter & Unit & Measurement method & Notes \\
\hline slope gradient & degrees & clinometer & average slope and local steepest gradients \\
\hline slope aspect & degrees & compass & recorded in the middle of the land unit \\
\hline fine earth texture & $\begin{array}{l}\text { qual- } \\
\text { itative }\end{array}$ & 'feel' method & \\
\hline $\begin{array}{l}\text { rock fragment } \\
\text { cover }\end{array}$ & $\%$ & $\begin{array}{l}\text { grouping of all rock } \\
\text { fragments in one corner } \\
\text { of a square }\end{array}$ & estimated in a representative sample area \\
\hline rock fragment size & $\mathrm{cm}$ & median diameter & $\begin{array}{l}\text { rock fragments: }>0.5 \mathrm{~cm} \text {; in erosion } \\
\text { processes, smaller particles behave as sand } \\
\text { rather than as rock fragments (Poesen et al., } \\
1998 \text { ) }\end{array}$ \\
\hline $\begin{array}{l}\text { vegetation cover } \\
\text { by grasses and } \\
\text { herbs }\end{array}$ & $\%$ & $\begin{array}{l}\text { visual estimate in the } \\
\text { field }\end{array}$ & \\
\hline tree canopy cover & $\%$ & $\begin{array}{l}\text { visual estimate in the } \\
\text { field }\end{array}$ & $\begin{array}{l}\text { adjustment to summer conditions done for } \\
\text { observations outside of summer period }\end{array}$ \\
\hline tree species & $\begin{array}{l}\text { qual- } \\
\text { itative }\end{array}$ & & $\begin{array}{l}\text { efficiency to stabilise slopes may vary with } \\
\text { species }\end{array}$ \\
\hline $\begin{array}{l}\text { expression of } \\
\text { combustion } \\
\text { phenomena }\end{array}$ & $\begin{array}{l}\text { dimens- } \\
\text { ionless }\end{array}$ & $\begin{array}{l}\text { ordinal scale of } 0 \text { to } 3 \\
\text { (none }- \text { few }- \text { much }- \\
\text { very much). }\end{array}$ & impact on vegetation and on slope processes \\
\hline $\begin{array}{l}\text { direct human } \\
\text { impact }\end{array}$ & $\begin{array}{l}\text { qual- } \\
\text { itative }\end{array}$ & & $\begin{array}{l}\text { trampling, wood cutting, garbage disposal, } \\
\text { motor cycle riding }\end{array}$ \\
\hline
\end{tabular}


Table 3

Correlation $(r)$ between explanatory factors of slope processes on the Petite Bacnure coal tip, as observed at grid cell scale $(20 \times 20 \mathrm{~m} ; n=320)$

$\begin{array}{ccccccc}\begin{array}{c}\text { Slope aspect } \\ \text { (degrees) }\end{array} & \begin{array}{c}\text { Slope } \\ \text { gradient } \\ \text { (degrees) }\end{array} & \begin{array}{c}\text { Rock fr. } \\ \text { cover }\end{array} & \begin{array}{c}\text { Rock fr. } \\ \text { size }(\mathrm{cm})\end{array} & \begin{array}{c}\text { Grass } \\ \text { cover }\end{array} & \begin{array}{c}\text { Tree } \\ \text { cover }\end{array} & \begin{array}{c}\text { Total } \\ \text { vegetat } \\ \text { ion } \\ \text { cover }\end{array}\end{array}$

$(\%)$

\begin{tabular}{|c|c|c|c|c|c|c|c|}
\hline $\begin{array}{l}\text { Slope gradient } \\
\text { (degrees) }\end{array}$ & $0.34 * * *(\mathrm{~S})$ & & & & & & \\
\hline $\begin{array}{l}\text { Rock fr. cover } \\
(\%)\end{array}$ & $0.60 * * *(\mathrm{E})$ & $0.21 * * *$ & & & & & \\
\hline Rock fr. size $(\mathrm{cm})$ & $0.34 * * *(\mathrm{~W})$ & $-0.37 * * *$ & $-0.41 * * *$ & & & & \\
\hline Grass cover $(\%)$ & $0.38^{* * *}(\mathrm{SE})$ & $-0.10^{*}$ & $-0.43 * * *$ & $0.52 * * *$ & & & \\
\hline Tree cover $(\%)$ & $0.43 * * *(\mathrm{NE})$ & $-0.12 * *$ & $0.17 * * *$ & $0.10 *$ & $-0.73 * * *$ & & \\
\hline $\begin{array}{l}\text { Total vegetation } \\
\text { cover }(\%)\end{array}$ & $0.22 * * *(\mathrm{~W})$ & $-0.27 * * *$ & $-0.34 * * *$ & $0.82 * * *$ & $0.31 * * *$ & $0.41 * * *$ & \\
\hline Combustion $^{1}$ & $0.52 * * *(\mathrm{SE})$ & $0.18^{* * *}$ & $-0.19 * * *$ & $-0.10 *$ & $0.63 * * *$ & $-0.61 * * *$ & 0.00 \\
\hline
\end{tabular}

${ }^{1}$ Combustion is expressed on an ordinal scale, promoted to a quantitative interval scale (see section 2.4.2.) *** Significant at 0.01 level; ** significant at 0.05 level; * significant at 0.1 level; all other coefficients are not significant.

Table 4

Correlation $(r)$ between explanatory factors and slope processes ${ }^{1}$ on the Petite Bacnure coal tip, as observed at grid cell scale $(20 \times 20 \mathrm{~m} ; n=320)$

\begin{tabular}{|c|c|c|c|c|c|c|c|c|}
\hline $\begin{array}{l}\text { Slope } \\
\text { processes }\end{array}$ & $\begin{array}{c}\text { Slope aspect } \\
\text { (degrees) }\end{array}$ & $\begin{array}{c}\text { Slope } \\
\text { gradient } \\
\text { (degrees) }\end{array}$ & $\begin{array}{c}\text { Rock fr. } \\
\text { cover } \\
(\%)\end{array}$ & $\begin{array}{c}\text { Rock fr. } \\
\text { size } \\
(\mathrm{cm})\end{array}$ & $\begin{array}{c}\text { Grass } \\
\text { cover } \\
(\%)\end{array}$ & $\begin{array}{c}\text { Tree } \\
\text { cover } \\
(\%)\end{array}$ & $\begin{array}{c}\text { Total } \\
\text { vegetation } \\
\text { cover }(\%)\end{array}$ & $\begin{array}{l}\text { Combust } \\
\text { ion }\end{array}$ \\
\hline $\begin{array}{l}\text { Creep } \\
(n=309)^{2}\end{array}$ & $0.78 * * *(\mathrm{~N})$ & $-0.21 * * *$ & $-0.15 * * *$ & $0.30 * * *$ & $-0.29 * * *$ & $0.64 * * *$ & $0.30 * * *$ & $-0.60 * * *$ \\
\hline Sheet erosion & $\begin{array}{c}0.51 * * *(\mathrm{~N}) \\
0.75 * * *\end{array}$ & -0.06 & $-0.33 * * *$ & $\begin{array}{c}-0.14 * * \\
-\end{array}$ & $-0.65 * * *$ & $0.62 * * *$ & $\begin{array}{c}0.01 \\
-0.45 * * *\end{array}$ & $-0.62 * * *$ \\
\hline Rill erosion & (NE) & 0.06 & $0.28 * * *$ & $\begin{array}{c}0.35 * * * \\
-\end{array}$ & -0.05 & $-0.27 * * *$ & $-0.10 *$ & $0.20 * * *$ \\
\hline Gully erosion & $\begin{array}{c}0.80 * * *(\mathrm{E}) \\
0.33 * * *\end{array}$ & 0.03 & $0.76 * * *$ & $0.18 * * *$ & $-0.32 * * *$ & $0.24 * * *$ & $-0.25 * * *$ & $-0.18 * * *$ \\
\hline $\begin{array}{l}\text { Landsliding } \\
\text { Rock fr. }\end{array}$ & $(\mathrm{SW})$ & $0.12 * *$ & -0.02 & -0.06 & $0.40 * * *$ & $-0.57 * * *$ & -0.05 & $0.20 * * *$ \\
\hline sliding & $\begin{array}{c}0.44 * * *(\mathrm{~W}) \\
0.60 * * *\end{array}$ & 0.09 & $0.32 * * *$ & -0.04 & $-0.14 * *$ & $0.10^{*}$ & $-0.23 * * *$ & $-0.19 * * *$ \\
\hline Deposition & $\begin{array}{c}(\mathrm{SW}) \\
0.23 * * *\end{array}$ & $0.10^{*}$ & $-0.29 * * *$ & $-0.12 * *$ & -0.07 & $-0.13 * *$ & -0.08 & $-0.12 * *$ \\
\hline Root throw & $(\mathrm{NE})$ & $-0.35 * * *$ & $0.11 *$ & $-0.10 *$ & $-0.20 * * *$ & $0.14 * *$ & & $-0.13 * *$ \\
\hline
\end{tabular}


Table 5

Correlation $(r)$ between explanatory factors and rill erosion on all studied coal tips as observed at grid cell scale $(20 \times 20 \mathrm{~m})$

\begin{tabular}{|c|c|c|c|c|c|c|c|c|c|}
\hline & $n$ & $\begin{array}{c}\text { Slope } \\
\text { aspect } \\
\text { (degrees } \\
\text { ) }\end{array}$ & $\begin{array}{c}\text { Slope } \\
\text { gradient } \\
\text { (degrees } \\
\text { ) }\end{array}$ & $\begin{array}{c}\text { Rock fr. } \\
\text { cover } \\
(\%)\end{array}$ & $\begin{array}{l}\text { Rock fr. } \\
\text { size }(\mathrm{cm})\end{array}$ & $\begin{array}{c}\text { Grass } \\
\text { cover }(\%)\end{array}$ & $\begin{array}{c}\text { Tree } \\
\text { cover }(\%)\end{array}$ & $\begin{array}{c}\text { Total } \\
\text { vegetation } \\
\text { cover }(\%)\end{array}$ & $\begin{array}{c}\text { Combustio } \\
n^{1}\end{array}$ \\
\hline $\begin{array}{l}\text { Petite } \\
\text { Bacn } \\
\text { ure }\end{array}$ & 320 & $\begin{array}{l}0.75^{* * * *} \\
\mathrm{NE}\end{array}$ & 0.06 & $0.28 * * *$ & $-0.35 * * *$ & -0.05 & $-0.27 * * *$ & $-0.45 * * *$ & $0.20 * * *$ \\
\hline $\begin{array}{l}\text { Hasar } \\
\text { d }\end{array}$ & 483 & $\begin{array}{c}0.13 * * * \\
\mathrm{E}\end{array}$ & $0.27 * * *$ & $0.26 * * *$ & 0.01 & $-0.57 * * *$ & $-0.40 * * *$ & $-0.54 * * *$ & $0.14 * * *$ \\
\hline $\begin{array}{l}\text { Water } \\
\text { schei }\end{array}$ & 233 & $\begin{array}{c}0.70 * * * \\
\mathrm{~S}\end{array}$ & $-0.17 * *$ & -0.03 & -0.09 & $0.21 * * *$ & $-0.59 * * *$ & $0.14 * *$ & $\mathrm{~N} / \mathrm{A}^{2}$ \\
\hline $\begin{array}{l}\text { Boubi } \\
\text { er }\end{array}$ & 327 & $\begin{array}{c}0.44 * * * \\
\mathrm{SE}\end{array}$ & -0.05 & $0.12 * *$ & $-0.11 *$ & $-0.23 * * *$ & $-0.36 * * *$ & $-0.32 * * *$ & $-0.10^{*}$ \\
\hline $\begin{array}{l}\text { Hérib } \\
\text { us }\end{array}$ & 730 & $\begin{array}{c}0.49 * * * \\
\text { NW }\end{array}$ & $0.26 * * *$ & $0.37 * * *$ & $0.27 * * *$ & $-0.28 * * *$ & $-0.22 * * *$ & $-0.34 * * *$ & $0.19 * * *$ \\
\hline
\end{tabular}

Table 6

Slope aspects at which the greatest process intensity occurs, per geomorphic process (three ${ }^{1}$ dominant aspects in decreasing order)

\begin{tabular}{|c|c|c|c|c|c|c|}
\hline & Petite Bacnure & Hasard & Waterschei & Boubier & Héribus & Overall \\
\hline Creep & N-NW-W & - & $\mathrm{W}$ & - & - & NW \\
\hline Sheet erosion & N-SW-NW & SW-S-W & NW-W-N & $\begin{array}{c}\text { SW-NW-S- } \\
\text { W }\end{array}$ & $\begin{array}{l}\text { S-SW- } \\
\text { SE }\end{array}$ & $\begin{array}{l}\text { SW to } \\
\text { NW }\end{array}$ \\
\hline Rill erosion & E-NE-N & - & SW-S-SE & W-E-SE & NW-W & - \\
\hline Gully erosion & E-NE & S-SE & S-SW-SE & E-SE & - & - \\
\hline Landslide & SW & $\begin{array}{l}\text { N-NW- } \\
\text { NE }\end{array}$ & NE-N-W & $\mathrm{N} / \mathrm{A}^{2}$ & - & - \\
\hline $\begin{array}{l}\text { Rock fragment } \\
\text { displacement }\end{array}$ & W-NW & - & NE-E-SE & $\begin{array}{l}\text { E-NE-N- } \\
\text { NW }\end{array}$ & - & $\begin{array}{l}\text { NE to } \\
\text { NW }\end{array}$ \\
\hline Root throw & - & - & SW-S-SE & N-NE & - & - \\
\hline $\begin{array}{l}\text { All slope } \\
\text { processes }\end{array}$ & $\mathrm{N}$ to $\mathrm{W}$ & $\mathrm{S}$ to $\mathrm{W}$ & - & $\mathrm{NW}$ to $\mathrm{NE}$ & - & $\mathrm{W}$ \\
\hline Deposition & SW-S-W & SW-S-W & SW-S-W & E-SE-NE & - & $\mathrm{S}$ and $\mathrm{SW}$ \\
\hline
\end{tabular}

\footnotetext{
${ }^{1}$ Aspects are not represented when the process occurs at an intensity that is less than half of the intensity at the dominant aspect, or when the intensity of the process there cannot be clearly distinguished from that of several other slope aspects. ${ }^{2}$ Landsliding was not observed at the Boubier coal tip.
} 